Illinois State University

ISU ReD: Research and eData

Theses and Dissertations

$6-27-2017$

\title{
Images Of Women In Refugee Drama: Eve Ensler's Necessary Targets And Ellen Mclaughlin's The Trojan Women
}

Kaitlyn Tossie

Illinois State University, ktossie522@gmail.com

Follow this and additional works at: https://ir.library.illinoisstate.edu/etd

Part of the Feminist, Gender, and Sexuality Studies Commons, History Commons, and the Theatre and Performance Studies Commons

\section{Recommended Citation}

Tossie, Kaitlyn, "Images Of Women In Refugee Drama: Eve Ensler's Necessary Targets And Ellen Mclaughlin's The Trojan Women" (2017). Theses and Dissertations. 780.

https://ir.library.illinoisstate.edu/etd/780

This Thesis is brought to you for free and open access by ISU ReD: Research and eData. It has been accepted for inclusion in Theses and Dissertations by an authorized administrator of ISU ReD: Research and eData. For more information, please contact ISUReD@ilstu.edu. 
IMAGES OF WOMEN IN REFUGEE DRAMA: EVE ENSLER'S NECESSARY TARGETS

AND ELLEN MCLAUGHLIN'S THE TROJAN WOMEN

\section{Kaitlyn Tossie}

\section{Pages}

In the past ten years, a critique of the conceptualization of refugees in Western mass media has emerged as a developing discourse in response to post- $20^{\text {th }}$ century genocides. Photographs in mass media of wailing refugees began to appear in the early 1990s when reports of the Bosnian genocide appeared in the United States. These images, and the stereotypes that surround them, contribute to the universal depiction of refugees as weak. Though the way in which theatre comments on this conceptualization of refugees has largely been ignored, theatre has a unique ability to comment on, reflect, and create a culture that can contribute to the imagining of categories of people. Using theories rooted in Melodrama and trauma studies, this thesis looks at how historical stereotypes of women shape the way audiences imagine refugees in theatrical representations of genocide. In Eve Ensler's Necessary Targets and Ellen McLaughlin's The Trojan Women, three traditional stereotypes of women are portrayed: the mother, the hysterical woman, and woman as Other. This thesis examines how these plays use these stereotypes to juxtapose or reinforce these images.

KEYWORDS: Ellen McLaughlin, Eve Ensler, The Trojan Women, Necessary Targets, Stereotypes, Women, Refugees, Bosnian War, Genocide 
IMAGES OF WOMEN IN REFUGEE DRAMA: EVE ENSLER'S NECESSARY TARGETS

AND ELLEN MCLAUGHLIN'S THE TROJAN WOMEN

KAITLYN TOSSIE

A Thesis Submitted in Partial Fulfillment of the Requirements

for the Degree of

MASTER OF SCIENCE

School of Theatre and Dance

ILLINOIS STATE UNIVERSITY

2017 
(C) 2017 Kaitlyn Tossie 
IMAGES OF WOMEN IN REFUGEE DRAMA: EVE ENSLER'S NECESSARY TARGETS

AND ELLEN MCLAUGHLIN'S THE TROJAN WOMEN

KAITLYN TOSSIE

COMMITTEE MEMBERS:

Ann Haugo, Chair

Kyle Ciani

Kee-Yoon Nahm 


\section{ACKNOWLEDGMENTS}

I would first like to thank the following faculty members: Dr. Ann Haugo, Dr. Bruce Burningham, Dr. Kyle Ciani, and Dr. Kee-Yoon Nahm at Illinois State University. I appreciate the time, guidance, and support they have given me over the process of this project. I particularly want to thank Dr. Haugo and Dr. Nahm for reading my preliminary drafts and always being a source of guidance and encouragement. Their wealth of knowledge in both Feminism and stereotyping in theatre has been a welcome influence.

I would also like to thank my wonderful husband, Miles Tossie, for his constant support, love and encouragement throughout this process and course of study. I would like to thank my family and my dear friends (particularly Amanda Labonte and Treasure Davis) for their continuous support. This accomplishment would not have been possible without the wonderful people in my life.

Finally, I would like to acknowledge the playwrights whose work has inspired this project: Ellen McLaughlin and Eve Ensler. I am gratefully indebted to their creativity and passion for telling the stories of those whose stories often go unheard. Finally, I wish to dedicate this project to the Syrian refugees who have fled their home country in the last six years and the Bosnian women who were impacted by the genocide in the 1990s.

K. T. 


\section{CONTENTS}

Page

ACKNOWLEDGMENTS

CONTENTS

CHAPTER I: INTRODUCTION 1

Historical Stereotypes $\quad 4$

Feminism's Great Debate $\quad 11$

$\begin{array}{ll}\text { Chapter Overview } & 14\end{array}$

CHAPTER II: REFUGEE (MELO)DRAMA 16

Problem Plays: Refugee Drama and Theatre of Genocide 19

$\begin{array}{ll}\text { Melodramatic Lens } & 27\end{array}$

$\begin{array}{ll}\text { Migrant Melodrama } & 35\end{array}$

Suffering and Stereotypes in Migrant Melodramas 38

CHAPTER III: ENSLER'S NECESSARY TARGETS 43

Production History and Response $\quad 45$

Stereotypes in Necessary Targets $\quad 48$

Transnational Feminism: An Image of Maternalism 51

Hysteria and the Refugee $\quad 59$

$\begin{array}{ll}\text { Women Refugees as Others } & 63\end{array}$

CHAPTER IV: MCLAUGHLIN'S THE TROJAN WOMEN 69

Stereotypes of Women in The Trojan Women 75

$\begin{array}{ll}\text { Subversion of Stereotypes } & 75\end{array}$

$\begin{array}{ll}\text { The Mother/Nurturer Role } & 77\end{array}$

Cassandra: Hysterical Prophetess $\quad 82$ 


\section{CHAPTER I: INTRODUCTION}

In 1991, the roughly 4,000,000 people living in Bosnia-Herzegovina, which is now recognized as Bosnia, were formed by three major ethnic groups. The Bosnian Muslims (Bosniak) composed forty-four percent of the population, followed by Serb and Croat citizens with thirty-one and seventeen percent of the population's total respectively. By 1995, 100,000 of the Bosnia-Herzegovinian people were killed. Roughly eighty percent of those who were killed were Bosnian Muslims ("Bosnia-Herzegovina”). Over 2,000,000 citizens of Bosnia-Herzegovina were also either displaced inside the country or were forced to seek refuge in another nation (Returns to Bosnia...). This mass displacement, and what would later be called ethnic cleansing, was the result of a war over territory in the former Yugoslavia. Though all war is egregious, the Bosnian War stands out from others for several reasons. The two effects of the war that influence this study the most are the number of displaced people and the systematic rape of Bosnian Muslim women.

In the nearly four years that the Bosnian War raged on, up to 60,000 women were raped ("Background Information"). As part of the "ethnic cleansing” Bosnian-Serb soldiers raped Bosniak and Croat women in the hopes of impregnating these women, essentially eradicating the multiple ethnicities in Bosnia-Herzegovina. This is certainly not the first time that rape and forced impregnation has been used as a tactic of war, but the international outcry over the rapes during the Bosnian War was unprecedented.

By May of 1993, just over a year after the war began, the International Criminal Tribunal for the Former Yugoslavia (ICTY) was formed at The Hague, the Netherlands. Three years later, the tribunal announced that eight Bosnian Serb military and police officers would be charged with the rapes of women in Bosnia-Herzegovina. This marked the first time that rape would be 
charged as a separate war crime (Simons). The ICTY was also the first international tribunal since the Nuremberg trials ${ }^{1}$ and the first to prosecute genocide.

The American public's concern with rape in Bosnia-Herzegovina was, in part, a direct result of the rape crisis and sexual assault awareness movements in the United States. As national conversation grew in the early 1990s, Americans became more sensitive to the sexual injustice experienced by women internationally. This awareness encouraged indictments of those who had committed rapes and sexual assaults during the Bosnian War. However, this public response, particularly in the United States, was a delayed reaction to the Balkan Wars.

Americans were, initially, misguided and kept in the dark regarding the conflict in the Balkans. The Western mass media was largely responsible for providing information to the public and played a major role in bolstering public outcry during the Bosnian War and subsequent genocide; the U.S. government steered the conversation away from BosniaHerzegovina and framed the conflict as a civil war. Though the U.S. government suspected that the Bosnian War would likely occur and the conflict could result in the deadliest war in the Balkans, the government chose not to intervene militarily because the interests of the U.S. were not immediately at stake (Powers 252; 261; 266). Even when government officials knew about the use of concentration camps, they did not initially act. The U.S. government withheld information about these camps until high-profile news sources began to broadcast reports about the camps in July 1992. However, Richard Boucher, the State Department spokesman, implied that the concentration camps were not to the "Holocaust standard" (271). This Holocaust standard would never be met, but the images of "wilting Muslims behind barbed wire", broadcast by the Independent Television News in England, would be a reminder of the images of the

\footnotetext{
${ }^{1}$ Those tried at Nuremberg were charged with conspiracy, crimes against peace, crimes against humanity, and war crimes. Though Raphael Lemkin coined the term 'genocide' by the start of the trials, genocide was not yet a legal crime those on trial could be charged with.
} 
Holocaust (276). These images would enrage the public and began to point the attention of government officials and grassroot organizations to the horrors of the Bosnian War.

This comparison to the Holocaust still looms over the ethnic cleansing that occurred in Bosnia-Herzegovina. The twenty-fifth anniversary of the Bosnian War and the seventy-second anniversary of the liberation of Buchenwald both occurred during April 2017. To my knowledge, the Western mass media largely covered the anniversary of the liberation while no major U.S. news outlets reported on the Bosnian anniversary.

The initial lack of media and government coverage should not be surprising. During the war, many journalists did not believe the stories the first wave of refugees told them. This had three primary causes. Firstly, journalists could not believe the horrific stories refugees told them. How could reporters believe concentration camps were being created, a nation was being ethnically cleansed, women were being systematically raped, and the international community had very little immediate response to the Bosnian conflict when the world promised that such atrocities would never happen again? Again, the experiences of the Bosnian refugees were placed in comparison to the Holocaust. Secondly, journalists struggled to determine the credibility of Bosnian refugees. According to Laura Pitter, a freelance journalist, the refugees seemed to be credible in the traditional sense, but their stories were too similar and too hard to believe (Powers 270). Though refugees were widely experiencing similar horrors, it appeared to many reporters that these stories were likely to be rumors. The refugee testimony was largely denied. Finally, refugees were often not believed because of their appearance. Early waves of refugees were a tough sell for reporters — refugees "did not have the sunken cheeks and haunted stare of the displaced in Rwanda or Somalia.”. Other refugees described situations where they were forced to abandon their expensive vehicles at the bottom of a mountain as they escaped, 
many refugees wore expensive looking jewelry, were educated and had well-respected jobs prior to the war (Ricchiardi). The stereotypical image of a refugee is one who is poor, perhaps dirty, and tired. They are often imagined as being weak or fragile because they were unable to handle their experiences back home. The stereotypical refugee is a woman who is afraid. When refugees do not fit this stereotype, their story is challenged. These initial victims did not quite fit the narrative or image of refugees fleeing war.

\section{Historical Stereotypes}

Fortunately, the theater is a place where refugee testimony can be shared rather openly and the stereotypes of refugees can be pushed to the side. Historically, theatre artists tend to gravitate towards times of duress. The Bosnian War is certainly no different in this aspect. The plays written or adapted in response to the Bosnian War typically fall under one of two categories: the refugee drama or theatre of genocide. The term theatre of genocide, as coined by Robert Skloot describes plays as:

...theatrical investigations of genocide [...]. Their artistic strengths - exciting action, evocative language, provocative engagement with difficult themes - make their contribution to the discussion and prevention of genocide noteworthy. Their author's purpose is to bring audiences closer to both recent and distant historical periods of violence through the dynamics of theatre performance. (5)

To my knowledge, no scholar has defined or used the term refugee drama. For this study, I am choosing to define refugee drama as a theatrical work exploring the refugee experience with elements of melodrama. One of these elements that refugee dramas may rely on is the use of stereotypes. The remaining melodramatic elements will be further discussed in the next chapter. The focus of this project will be on the refugee drama and the images of female refugees in such 
plays. Focusing on two plays written in response to the Bosnian War and subsequent genocide, Eve Ensler's Necessary Targets and Ellen McLaughlin's adaptation of The Trojan Women, I will examine how traditional stereotypes of women are used in refugee drama. I will also explore how performances by and about refugees evoke sympathy from the audience, specifically an audience in the United States, and how these performances subvert and/or fall back to traditional images of women.

Before I identify the exact stereotypes that I will be examining in this study, a closer look at what stereotypes are, why they are produced and reinforced, and how stereotypes operate is necessary. To begin this portion of the study, I will use Gordon Allport's definition of a stereotype, which many scholars have used as a foundation for their work. Allport says, "Whether favorable or unfavorable, a stereotype is an exaggerated belief associated with a category. Its function is to justify (rationalize) our conduct in relation to that category." (191). Though Allport does not specifically address this in his definitions, these exaggerated beliefs are most often applied to broad categories of people, such as women or refugees. Michael Pickering expands on this understanding of stereotypes and categories in his book Stereotyping: The Politics of Representation. Pickering breaks down the concept of categories as a way in which we organize and can understand the world around us (3). This concept is not inherently bad or dangerous to the understanding of others, but the stereotypes which are generally a result of categorizing people are often precarious.

Stereotypes, unlike categories, deny flexibility to those "exaggerated beliefs" and, in turn, justify the way we interact with others. Stereotypes are used to uphold the status quo regarding social, economic, and political order and are created by those who hold the most power in society. For the power to remain in its current hands, the powerful form definitions of identity 
and evaluations for those with less power (Pickering 3). Homi Bhabha, a scholar who Pickering references several times in his work, suggests that stereotypes "must be anxiously repeated" by those in power for the status quo to remain the same (66). This anxious repetition of stereotypes is so essential because the use of stereotypes creates a meaning to one's identity, regardless of whether they are the one creating or receiving the stereotype, and often determines differences between groups (Hall 3). This is incredibly important to those who create and reinforce stereotypes.

Stereotypes mark a category of people as homogeneous; those in said category are then diminished to simplified characteristics that determine what it means to be part of that category. This often creates a sense of superiority or security for those who resort to the use of stereotypes (Pickering 4). Pickering claims that "If a social group or category is stereotyped [...] the ascription acts not only as a marker or deviancy, making it marginal to the moral order, but also as a revalidation of that which it is measured against and found wanting." (5). I would also suggest that stereotypes not only define the perceived normal and those who fail to live up to that standard, but create confusion when one deviates from the stereotype. This is partially because the stereotype speaks only to the values and limited understanding of those in power, not to those who are stereotyped (7).

Another term that is relevant to this study and the understanding of stereotypes is the 'Other'. Pickering again jumps off the work of Bhabha and his understanding of the Other. Bhabha claims that stereotyping categories of people is a strategy to create an object/Other (66). Pickering argues that the Other is a much more modern and advanced concept than the stereotype; the Other always alienates the object of the stereotype regardless of whether the 
stereotype is positive or negative. The Other also points to the stereotypical as being the object, while those who produce or reinforce the stereotype become the subject (Pickering 71).

Women have long been both the object of stereotyping and the Other regarding the dichotomy of gender. For the rest of this study, I will be using the word 'gender' to refer to the performativity of being either male or female. My intent is not to ignore the wide range of gender performativity, but to point out the stereotypes that have been placed on women's identities by their male counterparts. I will be analyzing three specific, historical images of women that are present in both McLaughlin's The Trojan Women and Ensler's Necessary Targets: The Mother/Nurturer, the Crazed/Hysterical Woman, and the Objectified Other.

Historically, there have been two images of women that fall under the Mother/Nurturer stereotype. The image of the good/self-sacrificing mother and the fallen mother, who is often one to abandon their children, are conspicuous in English literature. These images of motherhood were prominent in the English Victorian Era. The image of motherhood and an ideal femininity began well before the Victorian Era, however this period saw a great manifestation of these images that influenced American thinking centuries ago and has had an enduring impact on contemporary generations. I will use examples from literature in the $19^{\text {th }}$ century to point to these crystalized manifestations.

In the poem "The Angel in the House", written by Coventry Patmore, the ideal woman is described. She is both pious and self-sacrificing. Similar pieces of literature written in the mid to late 1800s, such as John Ruskin's “Of Queens' Gardens”, label women as virtuous nurturers. These women were also there to support their husbands while remaining obedient to his decisions (Leslie 35). It is significant to note that both works were written by men. This image of 
the pious, virtuous, obedient nurturer was not created from the knowledge and perspective of women; they were, instead, created from the values of Victorian era men.

The stereotype of the "good" mother, like other stereotypes, had real-world consequences. In Victorian England, this stereotype greatly influenced which single mothers received public assistance. Victoria Leslie describes the Foundling Hospital's process in determining which children the hospital would take in off the streets. The hospital staff, once the demand became too high, chose to focus their admission criteria on the integrity of the mother. For her children to receive aid from the hospital, the mother's character would be evaluated (35). The decisions of whether to accept her children and whether her character was respectable fell to the all-male committee. Once again, the image of the "good" mother rested on the shoulders of the gender with the most power.

Similarly, the image of the "bad" mother appears in the Victorian era and is the creation of men. Leslie calls this image of the bad woman/mother the "fallen woman". This woman was once respectable - perhaps she was the dutiful and nurturing wife and mother - but fell from grace. In most examples of the fallen woman, the woman is married and had extra-marital affairs which ruined her family (Leslie 36). This example can be understood in a broader sense, however. The fallen woman could also apply to a woman who no longer abided by the Victorian era rules of femininity, and, therefore, effectively ruined her character and family. Interestingly, Leslie points out that this image of the fallen woman was a direct response to the rise of feminism in the late nineteenth century - a threat to the power of men. In 1857, men in Victorian England could divorce their wives for any affairs she may have had. Women, on the other hand, had to find fault beyond their husband's affairs to justify divorce (Leslie 38). As feminists began to argue that women should have the same basic rights as men (such as the rights 
to divorce and to retain custody of their children), the image of the fallen woman was created to keep women in their place.

The image of the "good" and "bad" mothers/women were not the only prevalent stereotypes of women in the nineteenth century. The hysterical woman was an image that plagued many women, some of whom were experiencing what would later be acknowledged as mental illnesses. Hysteria is defined as "a psychoneurosis marked by emotional excitability and disturbances of the psychogenic, sensory, vasomotor, and visceral functions...behavior exhibiting overwhelming or unmanageable fear or emotional excess" ("Hysteria"). Wendy Mitchinson, a historian who has studied hysteria specifically in Victorian era Canada, claims that late nineteenth-century doctors would agree with the second half of that definition (280). Mitchinson expands on this: "Historians agree that most individuals deemed hysterical in the late nineteenth century were women, although they disagree why this was the case. Feminist historians have argued that hysteria was a psychological response to the limitations placed on women's lives." (280-281). Women being diagnosed with hysteria is a common theme in Victorian literature. The short story "The Yellow Wallpaper” by Charlotte Perkins Gilman is an example of a piece of Victorian literature written about a woman who has been diagnosed with hysteria, by a woman who also had similar experiences. Gilman's narrator confides in the reader that she has been diagnosed with a form of depression and her husband has taken her to a large house outside of town. The narrator is not allowed to work or write; she must rest. When being locked in a house becomes unbearable, the narrator begins to become fixated on the yellow wallpaper in her room. Her husband threatens to take her back to her doctor if she does not behave. Towards the end of the story, she describes her wallpaper looking as though a woman is 
trying to escape from the confines of the main print. This is her imagination confronting her lack of agency in both her healthcare and marriage.

Though feminists argue that hysteria is a psychological response to lack of agency in women's lives, others believe hysteria was more of an attention-seeking strategy or a fake illness. Whether hysteria is considered a legitimate or a fabricated illness is of little significance to this study. The vital importance, however, is the role those in power, particularly men, have played in diagnosing women with hysteria, as well as the issue of using hysteria to describe both the over-use of emotion and trauma-induced mental illnesses such as Post-Traumatic Stress Disorder (PTSD). In this study, this dichotomous relationship between power and hysteria is prevalent.

The final image of women that will be examined is that of the Objectified Other. Women have been objectified since the beginning of advanced civilization, though the way in which this objectification occurs has slightly changed. The use here of the term 'objectified' or 'objectification' refers to the degradation of women to subservient beings, chattel and sexual possessions. This type of objectification, specifically women being reduced to secondary and submissive beings, occurred in fourth and fifth century BC Greece. David Pritchard points to the limited rights women had in democratic Athens. He suggests that marriages were arranged and one of the primary tasks for women was to reproduce (180). Women were kept in separate rooms of their home away from visiting men, were not allowed to leave their homes unless they absolutely had to and were kept out of few from men who might be passing by their windows (185). This behavior was not to keep women safe from men, but to protect men from engaging in any sort of contact with a woman who they were not related to. With such limited rights, even in her own home, it is not difficult to see how Classical plays like Lysistrata are viewed as 
comedies. If women were thought to be too promiscuous, were not allowed to leave their homes, or even attend some public events, it would be absurd for a group of women to conspire to withhold sex from their husbands and take over the acropolis to end a war.

Women's bodies, especially those of non-Western origin, have also been historically objectified. One of the most well-known cases of this Western objectification on the nonWestern body is that of Sara 'Saartjie' Baartman. Saartjie was an African Khoikoi woman who, in the late eighteenth and early nineteenth century allegedly signed a contract which allowed an English man she met to take her to London and place her on display. The English man and his partners were interested in Saartjie's exoticism and large labia/vagina and buttocks. While she was on display in London, she wore only a loincloth; her nude body, ample physical features, and dark skin drew many people to her exhibit. Later in her life, she was examined by and displayed for doctors of various fields. Even after her death her body became an exhibit; her body parts were placed on display in a museum for almost 160 years after her death. Though some argue that Saartjie was complicit in her objectification because Saartjie allegedly signed a contract and earned money from her exhibition, others believe she was forced to participate in such activities (Parkinson). In any case, Saartjie was objectified because of her body and assumptions made about her sexuality. This is just one of many outrageous cases where women have been sexually objectified throughout history.

\section{Feminism's Great Debate}

Feminists have fought against these stereotypes and their negative effects in and out of the theater for decades. Since the beginning of the feminist theatre movement in the 1960 s, women in theatre have formed theories and practical methods of challenging the negative imagery of women. Throughout this study, I will examine the aforementioned stereotypes with 
an understanding of feminist performance theory and a history of feminisms. I will also reflect on the debate second-wave feminist had on their role in transnational and domestic issues, and how this debate impacts a reading of the two plays.

The second wave of feminism began in the 1960s and continued through the 1990s. Second wave feminists were primarily concerned with sexuality, reproductive rights, and women's participation and treatment in the family and workplace. Because of the multiple civil rights movements that occurred during this time and the rise in protests and similar modes of advocacy, the second wave is often associated with activism. This rise in activism and parallel nature to other civil rights movements motivated those who were often ignored by the first wave feminists (such as poor and non-Western women and women of color) to join the feminist movement. Women from radical, civil rights, and New Left organizations sometimes had few choices but to join the feminist movement as gender politics were often ignored by their previous organizations. Unfortunately, the needs of these new members were sometimes pushed to the side by traditionalist, White feminists.

This is where the second-wave feminist debate comes began. While some feminists worked with other civil rights movement, others felt that their voices were not heard in other organizations, specifically those which were co-ed. Some women felt that gender equality should be addressed first, before they could effectively assist other movements (Dorey-Stein). This ideology also promoted a sense of sisterhood and demonstrated that gender, race, and class injustice were all equal regarding oppression. This, of course, did not always sit well with those whose identities intersected between those multiple areas of injustice.

Many women who had traditionally been ignored by the White feminist movement wrote a variety of responses to this idea of sisterhood, sameness, and white, Western women's view on 
transnational feminism. Chrystos, a two-spirit, Native American poet, responded to second wave feminists that held these attitudes with their poem "White Girl Don't". Chrystos draws attention to the feminist's desire to "fix" issues in other/developing countries, yet often ignore the problems in their own country. Instead, Chrystos suggests that feminists open their eyes to the hungry bellies, genocide, and homeless epidemic in the United States.

Chandra Mohanty also commented on the issues that arose from second-wave feminism; Mohanty specifically focused on the "third world woman" and transnational feminism. In her introduction to Third World Women and the Politics of Feminism, Mohanty opens her discussion of the third world woman noting that part of what constitutes a third world woman is their residency in an "'imagined community” of third world oppositional struggles." (4). Mohanty uses the word 'imagined' here to signify the potential alliances that can be formed across nonphysical boundaries. Building off this, Mohanty defines the third world woman as one in an imagined community "with divergent histories and social locations, woven together by the political threads of opposition to forms of domination that are not only pervasive but also systemic." (4). These political threads of opposition are the struggles that arise from factors of identity, such as race, class and gender. Mohanty specifically points to refugees as potential third world women. Because of the oppression and assault from the men who attacked them, the role of the Western media and government, and the domination of visiting White feminists, the Bosnian refugees in this study can be potential third world women. Later, in her essay "Under Western Eyes: Feminist Scholarship and Colonial Discourses", Mohanty discusses the problems that arise in transnational feminism and transnational feminists' relationship to the third world woman. 
Though in-fighting is often viewed as a negative thing, this is not necessarily the case. This major debate in second-wave feminism showed a turning point in feminism and opened an opportunity for voices to be recognized which may not have been heard before. Feminists were beginning to understand how others are situated in the world. Feminists playwrights and critics (e.g. Jill Dolan, Peggy Phelan) in the world of theatre then translated this recognition of other voices into an understanding of their protagonists and female characters.

\section{Chapter Overview}

In the first chapter, I will take a closer look at refugee drama as a genre. The role the suffering of the protagonist(s) and sympathy from the audience plays in refugee drama will also be analyzed. I will also discuss some of the problems that arise when refugee dramas are written, produced, and viewed. This will lead to a comparison of refugee drama and melodrama. In this comparison, I will examine the role of stereotypes in melodrama, as well as key melodramatic concepts that will help better explain the relationship between melodrama and refugee drama. Finally, I will highlight the similarities between migrant melodrama and refugee drama. Both these genres focus on the circulation of images of refugees/migrants, utilize suffering as a commodity, and use melodrama as a foundation. Understanding these similarities and drawing on the current scholarship of migrant melodrama will be beneficial to the examination of The Trojan Women and Necessary Targets in the following chapters.

In the remaining two chapters, I will examine the stereotypes present in Eve Ensler's Necessary Targets (chapter two) and Ellen McLaughlin's The Trojan Women (chapter three). During this examination, the stereotype of the Mother/Nurturer, The Hysteric Woman, and The Objectified Other will be analyzed. While dissecting the stereotypes in The Trojan Women, I will be analyzing the roles of Andromache, Cassandra, Helen and the chorus of Trojan women. By 
focusing on the liberties McLaughlin took in her adaptation and the differences between her female characters and Euripides' characters, I highlight the potential for subversion and/or reinforcement of the stereotype of the mother, hysteric, and Other. The third chapter's analysis of Ensler's Necessary Targets will focus on the American characters will focus specifically on the American characters (J.S. and Melissa) and their role as mothers to the Bosnian women and J.S.'s place as protagonist. This chapter will also contain a discussion on Seada as the hysterical woman and the Othering of the Bosnian women by the Western media and the American characters. Finally, I will navigate the potential pitfalls in these two plays, as well as their successes. 


\section{CHAPTER II: REFUGEE (MELO)DRAMA}

The elements of melodrama that emerge in refugee drama are heightened emotionalism, clear division of good and evil, and use of stereotypes. These plays are sometimes also produced with refugees as actors (see McLaughlin's The Trojan Women, Peter Sellar's The Children of Herakles, and Ensler's Bosnian performance of Necessary Targets). Refugee drama intends to comment on the suffering and experience of refugees while evoking empathy, and perhaps sympathy, from the audience. These plays, specifically those in this study, do not necessarily have concrete resolutions to the fate of the protagonists/refugees; it is up to the spectator to conclude what happens at the end of the action.

A similar genre to the refugee drama is that of the theatre of genocide. This genre has been accepted by practitioners and scholars, but is rarely described. Building off of his definition of theatre of genocide, Skloot states,

Like all engaged art, it [theatre of genocide] seeks to comment on and influence public discourse through various strategies: by the description of the victims' suffering and the assertion of their essential worthiness, the discussion of the perpetrators' motivation, the presentation of images of healing and compassion, the evocation of empathy, the questioning of the proper use of historical knowledge, and even the expansion and dissemination of what the critic Susan Sontag called "collective instruction" of culture.

Refugee drama uses some of these same strategies to explore the refugee experience. Both genres use and describe the victim's suffering, which can evoke empathy from the spectator. By describing the victim's suffering, both genres tend to capitalize on humanity and victimhood to promote the worth of the victim. Refugee drama and theatre of genocide often imply that there is 
healing for the victims. To some extent, this is true; theatre allows victims to share their stories or see similar stories unfold onstage, which can be healing for those who have experienced some form of trauma. However, these performances may re-open an emotional wound, as well. It should be noted that not every form of refugee drama fully incorporates these strategies, but they are nonetheless a good way to begin understanding the elements of refugee drama.

The similarities between refugee drama and theatre of genocide do not stop at the strategies each genre uses. Many of the events that inspire the action of these plays are the same. Some of the plays, such as those examined in this study, fall somewhere between both genres. Both The Trojan Women and Necessary Targets were written about refugees that were displaced because of the Bosnian genocide. Theatre of genocide and refugee drama, like their subjects, are not necessarily mutually exclusive.

The theatre of genocide and refugee dramas are perhaps more relevant than ever to consider and study. Though these plays will not bring immediate change to our society, they clarify the world we live in and perhaps can, eventually, make that world a better place (Skloot 6). Westerners, particularly those in the United States in today's political climate, are depicted by the mass media as being afraid of refugees and concerned with the consequences of allowing refugees into the country; perhaps these plays can counter these depictions and shed light on the similarities between refugees and natural citizens. With the current refugee crisis in Europe, with refugees primarily fleeing from Syria, understanding the experience of those who seek refuge in a new place is quite important.

The current crisis stems from the beginning of the 2011 civil war in Syria. Frustrated with the economic landscape and lack of freedoms, tensions grew between Syrian rebels and the Syrian government lead by President Bashar al-Assad. The nearly seven-year civil war has 
displaced more than $12,000,000^{2}$ Syrians from their homes. This is roughly half of the country's pre-war population ('Syria’s Civil War...”).

There are several similarities between the Bosnian and Syrian refugee crises. The most obvious similarity is the amount of people impacted, often forced to leave their homes, by both events. Secondly, both crises were the product of a civil war in which the government was primarily to blame. In the Bosnian war, the Bosnian-Serb government refused to acknowledge the separation of Bosnia-Herzegovina. The Syrian government was unconcerned with the lack of rights Syrian citizens had. Both governments, at the very least, showed little remorse for the relentless attacks on civilian lives. Thirdly, the primary victims of each war were Muslim. This is interesting when the response for both crises is considered. In a country that is deeply rooted in a Christian faith, and a growing population which disdains Islam and its followers, the response in both cases was often apathetic. The United States played a very small role in resolving the conflict in either case. During his time as President, Barack Obama firmly stated the United States' oppositional stance regarding the Assad regime, but hesitated to act on that opposition. The Western mass media has mostly strayed from covering the civil war in Syria and, as stated earlier, did not cover the Bosnian crises until images of Holocaust-like circumstances appeared. Today, the mass media primarily focuses on the Syrian crisis when a body of a child is found after washing up on the shores of Turkey or a bomb is dropped on a house leaving a stunned child abandoned in an ambulance. The issue with reporting only on these instances, as well as writing plays about genocide and the trauma of refugees, is the possibility of refugees and victims of genocide appearing weak and unable to care for themselves. This can result in the loss of agency for refugees and victims of genocide.

\footnotetext{
2 This number includes Syrians who have fled their homes to other locations in Syria and those displaced internationally.
} 


\section{Problem Plays: Refugee Drama and Theatre of Genocide}

Of course, there are many other pitfalls that entrap playwrights of both genres. One of these issues is the commodification of suffering. To evoke empathy from the audience, a playwright or director must be able to form a connection between the audience and the character. Most theatre of genocide and refugee dramas do not struggle with this connection as the major force in the play is the suffering of the victim/refugee. By capitalizing on the victimhood of their protagonists, playwrights and directors can easily turn the evocation of empathy into a commodification for consumption for audiences. When an entire genre of literature or performance surrounds the suffering of a group of people, the importance or shock of that suffering can be lost. Playwrights and directors must find the balance between over capitalizing on the suffering of their protagonist, often creating an exchange of suffering for a quick catharsis in the audience, and evoking true emotion in the audience that may linger with the spectator well after the performance is over. Consuming the suffering of others, and producing a catharsis in return, can create a stagnation in action after the performance. Audiences who experience the quick catharsis, may feel as if the work is already done and they do not need to act on the message or call to action of the production. This lack of motivation to act can certainly slow social change.

However, the evocation of empathy can eventually lead to sympathy. Bruce McConachie tracks the process of creating sympathy in the theater; he argues that the spectator must empathize with the character before they can experience sympathy. The initial simulation, or empathy, is followed by what McConachie calls the "spectatorial judgement". During this phase, the spectator must judge whether the character's position, experience, and behavior is worthy of sympathy. Once the spectator concludes that the character is worthy, the spectator allows 
themselves to experience a "feeling response"/sympathy (76). This concept can be troublesome for two opposing reasons which each stem from the spectator's position of power over the character/actor. Creating a judgement about a character/actor's worthiness can become an issue when the spectator comes to the theater with a preconceived bias about the category of people the character belongs to. For instance, should a spectator in the United States attend a refugee drama performance with anxiety or fear based on their preconceived prejudice towards refugees, the spectator's power to determine the character/object/actor's worthiness can be problematic. Conversely, feeling sympathetic towards the character/object/actor in a way in which they are seen as inferior or unable to care for themselves can reinforce a troublesome power dichotomy between the First and Third world, and will be discussed in more detail in the next chapter.

Another problem that arises when refugee dramas are written is that the story, and potential for dangerous use of stereotypes, is generally under the control of an "outsider". Most of the refugee dramas are written by those who are not refugees themselves - though there have been recent cases of Syrian refugees producing their own stories in grassroot theaters around the world, particularly in Lebanon and Jordan. There are instances where plays have been written based on interviews with refugees, such as Necessary Targets. Though plays of this nature are likely to be less dangerous to the image of refugees than those written based on an outsider's understanding of the refugee experience, plays like Necessary Targets are still written through the perspective of the outsider. In the case of McLaughlin's The Trojan Women, the refugees that McLaughlin worked with did have some form of agency in determining what was in the script. However, the final product was still firmly in McLaughlin's' hands.

The absence of refugees in the process of writing stories about their experience is troublesome as this act risks perpetuating the status quo. Aoife Monks, though she speaks to 
blackface in the Wooster Group's performance of The Emperor Jones, highlights this problematic continuation. Monks argues that the Wooster Group played with race for their mostly white audience with the use of whiteface and blackface, while highlighting the lack of black bodies on the stage. This is problematic as performing representations of both blackness and whiteness for a mostly white audience "preserves the status quo of racial representation". This same idea applies to refugee drama when refugees do not have a say in the writing and performance of their stories. Even if the intentions behind the project are good, when a refugee story is written and performed by non-refugees, for a non-refugee audience, the representation of refugees can be problematic. Monks later points to the destabilization that can occur when companies produce plays that challenge race, citizen status, gender, etc. but acknowledges that these same plays can be performed in a privileged context when there is an absence of those who identify as someone in those categories (558).

The first production of McLaughlin's The Trojan Women in 1996 at the New York City's Classic Stage Company was successful in diminishing the privileged context Monks speaks of. McLaughlin used input by the refugees she worked with to influence her script, the language used during the reading, character choices, and casting. McLaughlin used recent Bosnian refugees as the original actors for her play. She also used a combination of languages and dialects to highlight the diversity of her cast and audience. Ensler stumbles a bit more in her United States performances of Necessary Targets (1996). Though Ensler used interviews of Bosnian women, her script was largely written through her interpretation of those interviews and the women she interviewed. Non-refugees were also cast in the performances of Necessary Targets in the United States. However, perhaps where Ensler succeeds most is her choice of casting in Bosnia; refugees were cast in the performances that took place in Bosnia. 
The audience also contributes to the representation of refugees and the context in which these representations are performed. As Monks points to in her analysis of blackface in the Wooster Group's performance, when the audience is mostly comprised of those who are in power, the engagement of challenging subject matter, such as race and refugee status, is problematized (558). Similarly, when the audience of a refugee drama is primarily composed of non-refugees, the representation of refugees and their status can become an issue. When there are relatively few audience members who identify as refugees, the refugee characters can easily become tropes rather than humanized individuals. As I will explore in greater detail in the subsequent chapters, this can, of course, be a pitfall when a playwright or director is possibly attempting to subvert the traditional images of refugees. The first audience of McLaughlin's The Trojan Women was mostly made up of other refugees and those who supported the refugee community in New York City. McLaughlin's potential for subversion increased by having an audience that could identify with the same categories her characters would identify as and would likely recognized any subversion. Similarly, Ensler's Bosnian performance could have been successful in subverting the images of refugees and women. However, the performances of Necessary Targets in the United States may have fallen into the same trap that the Wooster Group fell into.

Juggling the stereotypes across multiple identities of the character/actor is another problem that often arises in refugee dramas. In his examination of subversion and reinscription of stereotypes in Mabou Mines' A Doll House, Kee-Yoon Nahm notes that even when audiences recognize that a stereotype is being subverted in a performance, problems can still arise. Nahm notes, "Some stereotypes span multiple identity positions, for example stereotypes of women of colour, so that an ironic citation may subvert one axis while uncritically reinforcing another." 
(94). This applies to the two plays analyzed in this study as there are multiple stereotypes used in each play: the refugee and the woman as mother, hysteric, and Other. Both playwrights risked the possibility of subverting one stereotype and reinforcing the other.

\section{Writing Trauma in Refugee Dramas}

One of the duties of the playwright/director when dealing with refugee dramas is being a responsible "secondary witness". Dominick LaCapra, a leading memory and trauma scholar, uses the term 'secondary witness' to describe someone who uses someone else's first-hand memory in their work. This first-hand memory is also known as the primary memory. LaCapra describes these two types of memory, and their respective witness, as follows:

Primary memory is that of a person who has lived through events and remembers them in a certain manner. This memory almost invariably involves lapses relating to forms of denial, repression, suppression, and evasion, but it also has an immediacy and power that may be compelling. Secondary memory is the result of critical work on primary memory, whether by the person who initially had the relevant experiences or, more typically, by an analyst, observer, or secondary witness such as the historian. (History and Memory 2021).

Though LaCapra is specifically working from a historical perspective and, therefore, refers to the historian in his work, the same idea can apply to the playwright/director. Like historians, playwrights and directors use research, often through documents, to track histories of events and people. Both historians and playwrights analyze their research to determine their importance and accuracy. Where these two fields differ is in their use and interpretation of the research; playwrights interpret documents and narratives to tell a story. The story being told by playwrights may be embellished, expanded, distorted, or reduced to express meaning and evoke 
emotion. Historians, on the other hand, focus on the particulars of research and examine it for accuracy. However, to say that "historical facts" are completely accurate is erroneous; historical data is also subjective and based on interpretation. Both historical analysis and playwriting can be useful methods of discovering and expressing primary testimony. Because of these similarities and both fields' usefulness in developing secondary memory, I will be referring to the playwright who works from primary memory of others as the playwright-historian.

One could consider playwrights such as McLaughlin and Ensler as playwright-historians; both have worked directly from the primary memory of those they interviewed and collaborated with. Part of the responsibility of these playwrights is to listen to the primary witness and respect their testimony (History and Memory 21). Balancing respect for one's memory with historical evidence can sometimes be difficult for the playwright-historian. This is often true when the memory of the primary witness does not necessarily line up with the historical "facts".

The secondary witness also faces an additional challenge of locating their position regarding the testimony of the primary witness. LaCapra states that the secondary witness, when they listen and use the testimony of a primary witness, "undergoes a transferential relation, and must work out an acceptable subject-position with respect to the witness and his or her testimony" (History and Memory 11). LaCapra uses the term 'transferential' to imply the impulse secondary witnesses often have to become emotionally connected to the primary witness and their testimony. This can sometimes lead to the secondary witness feeling as if they can somehow relate to the primary witness' testimony.

Playwright-historians have the additional responsibility of relaying the testimony of the primary witness to others who have not lived through the experience of the primary witness. According to LaCapra, "This procedure may require a muted or diminished transmission of the 
traumatic nature of the event but not a full reliving or acting out of it. It also requires an interpretation and estimation of what in memory is other than factual" (History and Memory 21). It is the responsibility of the secondary witness to translate the importance of the primary witness' testimony to their audience in a meaningful way. The challenge here is to respect the primary witness' testimony without appropriating the memory. In performance, this can be particularly difficult. Charles S. Maier claims that the objective of memory telling, specifically in secondary memory and in this case memory telling in the theater, is to "access [...] vivid and intense past experiences.”. These memory expressions rarely focus on the history of the primary witness, but instead display the "most painful incidents of victimization" in a person or group of people (Maier 144). Playwright-historians need to be cautious in their use of a witness's testimony; exaggerating memory and playing up gory details to evoke emotion from their audience is very problematic in genres such as refugee dramas and theatre of genocide.

LaCapra adds that "Memory [...] presumably gives direct access to experience, often vicarious experience, that may be sacralized [...] notably the traumatic experience of victimization." (History \& Memory 14). The vicarious experience can allow the audience to become a surrogate victim. When memory is performed on stage, it is often difficult for the audience to disassociate themselves from that memory; the connection between the audience and the actors can create a sense of empathy between the actor/character's testimony and the audience. The audience can, then, become implicated in the assumed shared trauma of the primary witness. This assumed shared trauma, as well as the performance of a traumatic event, can have an effect on the audience which "may raise problems of identity for others insofar as it unsettles narcissistic investments and desired self-images." (History and Memory 9). This unsettling of identity can have positive effects which challenge the assumed power dichotomy 
between the audience and actor/character and force the spectator to acknowledge their role in the performed trauma. Understanding one's role in the performed trauma and reconsidering the power relationship between the spectator and the character/actor can also assist in disproving stereotypical preconceptions of, in this case, refugees. As an audience member, reevaluating the similarities between oneself and the Other being performed on the stage can, perhaps, create an empathetic feeling that is much more productive than a feeling of assumed shared trauma or sympathy.

It is important to note that this empathy is not the same as the assumed shared trauma that sometimes follows these performances. LaCapra reiterates this point stating, ... empathy should not be conflated with unchecked identification, vicarious experience, and surrogate victimage. Empathy in this sense is a form of virtual, not vicarious, experience related to what Kaja Silverman has termed heteropathic identification, in which emotional response comes with respect for the other and the realization that the experience of the other is not one's own.

Hence the experience, including the affective response, of the historian is at issue in many complicated ways with respect to understanding. It helps to define the subject positions of the historian and may serve as an initial warrant to speak in certain voices. (Writing History 40).

The key to acknowledging the empathy one feels in the subject positions of historians, playwright-historians, or audience members in a safe manner is to keep a crucial, and perhaps objective, distance from the vicarious or assumed shared trauma. For the playwright-historian, this distance is especially important as they "attempt to form cogent judgments about what is desirable in the past and deserves to be reworked or flexibly reenacted (in contrast to 
compulsively acted out) in the present." (History and Memory 24-25). Deciding what is most helpful to rework or reenact in a safe environment, such as in the theatre, is challenging enough for playwrights and directors, but without a critical distance from the empathy and assumed shared trauma, objectively discovering what is most beneficial to the plot, the subject, those in the audience, and those performing, is near impossible. The assumed shared trauma that occurs when this distance is not achieved "should not be glorified or fixated upon". Instead, the playwright-historian should address the wounds of the past "in a manner that strives to be cognitively and ethically responsible." (Writing History 42). To achieve this ethical responsibility, we must first understand how refugee drama and theatre of genocide is written, understood, and processed. The first step in doing so is to acknowledge the foundational genre of both refugee and genocide dramas.

\section{Melodramatic Lens}

With empathy being at the center of refugee drama and genocide drama, their dramaturgies can be positioned in a genre known for its ability to evoke emotions: melodrama. Examining refugee drama in particular through a melodramatic lens is, to my knowledge, a new area of research. There are negative connotations of melodrama and the meaning of the genre has changed since its height in the early $19^{\text {th }}$ century, but looking through this lens can create an understanding of subgenres, like refugee drama, that scholars have yet to explore.

Peter Brooks, a major voice in melodramatic criticism, notes that melodramatic plays usually begin with a character presented as being virtuous and innocent. Unlike tragedies, melodrama highlights this virtuosity and innocence well before a crisis occurs. The climax is generally a threat from an outside force to obscure the virtuous picture at the beginning of the play (Brooks 29). Melodrama is regarded as a genre with heightened emotions - typically due to 
the emotionally charged scenes, situations, and characters. This indulgence in emotion, as well as extreme states of being and action, clear distinction between good and evil, and clear issues of morality, are all connotations of melodrama. These connotations are often used pejoratively as they are highlighted in low forms of melodrama, such as the soap opera and telenovela. However, these same elements allow audiences to experience the extremes of emotions, often leading to self-pity when one identifies with the protagonist (Brooks 11-12). The extremes of emotion that most frequently occur in melodrama are triumph, despair and protest. When these emotions work effectively, the audience experiences a catharsis (Smith 9). Though a catharsis at the end of a performance has traditionally been viewed as a positive aspect of theatre, catharsis can also lead an audience to become lackadaisical and feel unmotivated to act on the call to action. This is perhaps less concerning when the performance is intended for entertainment's sake, but when a performance and the message within are created to evoke action or change the audience's views on a given topic, a lethargic response in the audience can be dangerous.

This high emotionalism connects to the root of melodrama. Brooks notes that melodrama embodies the "need for dramatization, [...] for acting out." (Brooks 12). Coming from Sentimental Drama, and the lack of other entertainments designed for drawing out emotions in the early nineteenth-century, melodrama was designed to produce emotions in the audience. Melodrama, in short, is at the essence of drama; the purpose is to perform, or act out, feelings and dramatic events. This need for dramatizing high emotions and ethical conflict, which Brooks points to, ties into LaCapra's idea of acting out or working through trauma. For LaCapra, some, particularly those who have suffered severe trauma, may act out their trauma. This acting out is connected to mourning and remembering the trauma in a helpful way (History and Memory 6). Acting out does not necessarily mean dramatizing one's trauma, but this method could 
potentially help those working through their personal or cultural trauma. In artistic methods of acting out, the trauma is revisited in "more or less controlled artistic procedures" rather than “uncontrolled existential experiences." (History and Memory 7). Therefore, artistic forms of acting out are, perhaps, safer and more useful for revisiting one's trauma; melodramatic dramatization may be an effective tool for those who have lived through severe trauma such as genocide. Other forms of drama or genres can certainly be used in traumatic memory performance; however, with its foundation in sentiment, melodrama could possibly be a more useful method of mourning and remembering one's trauma.

Brooks also points to the melodramatic form as a response to the loss of what he calls the "tragic vision". He claims that melodrama "comes into being in a world where the traditional imperatives of truth and ethics have been violently thrown into question, yet where the promulgation of truth and ethics, their instauration as a way of life, is of immediate, daily, political concern." (Brooks 15). Melodrama has a way of connecting the audience to a time of perceived ethical stability. In times of crisis, the ability to briefly return to a time of ethical stability is certainly an attractive quality in melodrama. Therefore, melodrama may be a more effective genre to not only find comfort in the stark contrast between good and evil, but also develop a deeper desire to restore ethics and truth.

Finally, Brooks speaks to the characteristic of melodrama to express all feelings on the stage. Brooks says, "The Desire to express all seems a fundamental characteristic of the melodramatic mode $[\ldots]$ the characters stand on stage and utter the unspeakable, give voice to their deepest feelings, dramatize through their heightened and polarized words and gestures [...].” (Brooks 4). Again, Brooks' description of a fundamental trait of melodrama describes refugee drama and theatre of genocide quite well. Characters in these genres of plays give voice 
to the word of those who may not have been able to vocalize their trauma. How can one describe the trauma and horrors of genocide? It is these utterances that resemble those in refugee drama and theatre of genocide that also appear in melodrama.

\section{Understanding Refugee Drama Through a Melodramatic Lens}

James L. Smith ties vocalizations of trauma to Melodrama in his writings of the melodrama of war. Smith writes that one of the key features of melodrama is triumph. He uses the flight of refugees across difficult terrain as an example for triumph in melodrama of war (Smith 11). Smith points to the suffering and carnage of war as elements of melodrama of war as well. One of the plays Smith highlights in this section is Euripides' The Trojan Women. The despair of the Trojan women, extreme emotions of the women, and abandonment by Poseidon are some of the psychologically truthful elements used by Euripides. Smith goes as far as to say that, "The Trojan Women must rank as the greatest melodrama of military disaster ever written." (Smith 13-14).

Smith is not the only scholar to acknowledge Euripides as a proto-melodramatic playwright. Victor Castellani notes that though Euripides was said to be the most tragic of tragedians in the Greek Golden Age, his plays are often read by contemporary readers through a melodramatic lens. Castellani claims that Euripidean melodrama contains the following elements: “[...] a villainous and smug bully, a woman or women in distress, a child or children in mortal danger, and an unexpected rescue whose agent is either a rejuvenated old person or a person presumed dead or otherwise lost forever." (Castellani 1). Castellani notes that though many of Euripides' plays have some of these elements, only a few have all of them. Euripides' The Trojan Women finds a villain in both Talthybius and Menelaus and Astyanax is the clear child in mortal danger. All the Trojan women are in distress and despair as well. There is no 
rescue for the women in The Trojan Women, however. Even so, refugee drama plays, such as The Trojan Women, can still be considered melodramatic based on these elements and many others. I take Smith and Castellani's thoughts one step further and apply them to my analysis of The Trojan Women and other refugee dramas.

To begin, melodrama relies on stereotypes to create characters. These stereotypes allow characters to be under-developed. Audience members can fill in traits of the characters based on the stereotypes used in the drama. Brooks says that, "There is no "psychology" in melodrama [...], the characters have no interior depth, there is no psychological conflict.” (35). In melodrama, the central conflict of the drama is between the protagonist and someone else (the antagonist); the conflict is rarely a struggle between the protagonist and themselves. The characters are also given very basic backgrounds, if any at all, and their under-developed characteristics are determined by the stereotypes or categories the characters fall under. Similarly, the under-developed characters are dwindled down to their primary role in society and their relationships to others. Brooks notes that characters in melodrama "assume primary psychic roles, father, mother, child [...]." (4). The characters' identities are reduced to their societal or familial role.

Characters in refugee dramas are often like those in melodrama. In the case of The Trojan Women and Necessary Targets, characters are often under-developed and stereotypes are relied on to fill in the lacuna of the character's identity. The conflict is almost always between the protagonist and another character; the antagonist may not always appear as a physical character in the play but is referred to by the protagonist or other characters. This lack of psychological conflict, though there may be some psychological conflict in refugee dramas, is indicative of the psychological depth of the characters. Similarly, as later chapters will explore, the characters in 
the refugee dramas discussed in this paper are reduced to their familial role. In this case, the characters are mothers and fall into either the "good/nurturing" or "bad" mother category. Their character traits are then determined by the stereotypes surrounding these categories. Stereotyping is simply a convention of melodrama and though this convention can still be a practice of refugee drama, the stakes are significantly higher. Though the plays analyzed in this thesis primarily rely on stereotypes that can reinforce prejudice and cultural Othering, the stereotypes can be read in a different light and turned on their head. Tracing the issues and possibilities of subverting versus reinforcing stereotypes is the primary task of the following chapters.

Another similarity between melodrama and refugee drama is the role of female characters. Women are generally portrayed as virtuous, suffering heroines in both genres. Rosemarie K. Bank summarizes the characteristics of women in early American melodrama: [...] female characters [...] epitomized the ideal woman of that period - chaste, virtuous, nurturer of home and family, charitable servant and defender of the weak and downtrodden, loving wife, sister, sweetheart, and mother, loyal friend, and the cornerstone of a stable, productive and decent society. This image of women supported cherished preferences for certain kinds of female behavior, behavior which was rewarded by idolizing women as kinder-hearted and morally superior to men, albeit thereby more naïve and dependent, less rational and self-motivated, and unfit for the world of making and doing (240).

This type of character, and reading of her, is a traditional view of women in melodrama. The later melodramas in the late nineteenth and twentieth-century have more active women. According to Bank, these women worked outside the home, actively tried to solve the problems facing them rather than wringing their hands in despair, and they define the moral environment. 
Yet even these active characters have similar goals to those written in the early nineteenthcentury: to be a good wife or mother (Bank 240-241). Though late melodramas create female characters with more independence and power, the traditional characteristics Bank outlines seem to be forever imprinted on melodramatic, female characters. Like these traditional characteristics, refugees, specifically female refugees, are depicted in the Western mass media and entertainment as being helpless, incapable of caring for themselves and their families, or grieving widows and mothers. These are the images that are engraved in our minds.

The individual traits mentioned above display a pattern to portray women as docile, dependent, nurturing, and often inferior to men, individuals. Many of the female characters in melodrama are depicted as the "suffering heroine". This character is one of the many stock characters represented in melodramas. The suffering heroine is, perhaps, "the most important" character of those in melodrama (Smith 5).

The suffering heroine trope is quite popular in melodramas, particularly those written in the early nineteenth-century. However, this trope has appeared in melodramas, and other genres, well after the early nineteenth-century. One of these appearances is in The Octoroon by Dion Boucicault, a popular American melodrama. The suffering heroine in The Octoroon is Zoe, an "octoroon" in love with a white man from Europe who inherits the plantation Zoe works on. She is branded as Other because of her biracial background; she does not belong with the black slaves or the white plantation owners. She is an outsider to everyone else. In the world of the play, it is illegal for Zoe to marry George, her love interest in the play. Zoe is portrayed as a kind woman, loved by everyone she meets — including other white men — and always takes the accepted moral stance. While multiple men vie for her heart, Zoe declares that she cannot marry them, as it is against the law and unaccepted by society. She is unable to save herself from an 
unlawful and unwanted marriage to Jacob M'Closky; she must be saved by outside circumstances and the interventions of others.

One could also argue that Dora Sunnyside is also a "suffering heroine" in The Octoroon. Dora, like Zoe, falls in love with George and is willing to do everything in her power to make him happy. She is both a literal heroine in the story and suffers of a broken heart when her love for George is not returned. She has many of the ideal character traits mentioned above, as well. She purchases the plantation at the auction, even though she acknowledges that saving the plantation could allow George to marry Zoe. Though both Dora and Zoe are suffering heroines for different reasons, they both fit contrasting aspects of the trope.

It is important to note that stereotypes and tropes, such as the suffering heroine, were created long before the masses objected the stereotype and these images became politically charged. Similarly, the stereotypes of women and refugees, in general, were formed well before the feminist movements beginning in the 1800 s and the political activity surrounding refugees today. Melodramas, such as The Octoroon, The Trojan Women, and Necessary Targets have a knack for turning a social issue into a commodity for emotional consumption. In the case of this paper, the social issue examined is the plight of refugees and stereotypes of women. Melodramas, according to Smith, are "conventionally moral and humanitarian in point of view" (5). Melodramas take a social or political issue and dramatize it; this can be beneficial and shed light on the consequences facing those impacted by said issue, or it can have a negative outcome.

Generally, the cause for a potentially negative outcome through the dramatization of a social or political issue is caused by the emotional indifference of the audience. The cathartic experiences an audience undergoes can create a lack of desire to act on the injustice the audience witnessed in the play. After connecting to the protagonist or, particularly in the case of The 
Octoroon, the suffering heroine, the audience witnesses a sort of poetic justice which creates a catharsis for the audience. Even when the purpose of the play is to challenge stereotypes, social norms, and bring attention to social and political issues, the audience can become indifferent to the issue once a catharsis has been achieved. Justice is served in the play and, sometimes, the audience can feel that poetic justice is enough. When poetic justice appears to be enough, audiences will not act on the call to action. Instead, they have bought into the commodification of empathy.

\section{Migrant Melodrama}

A new sub-genre of melodrama has recently appeared in the Latinx film culture. The Migrant Melodrama genre focuses on the qualities of melodrama in films and plays that deal with migration, specifically the northern migration of solo children and mothers in South America and Mexico. Ana Elena Puga, one of the few scholars tackling this subject, has written several articles and is finishing a book on the qualities of melodrama, commodification of suffering and clear stereotypes in stories of migration for Latinx children and mothers. Migrant Melodrama contains many of the same elements as Refugee Drama and the topics are comparable. The major difference between the two genres is the perceived stark contrast between immigrants/migrants and refugees; refugees flee from their homes/cities for their own protection from a variety of circumstances, whereas immigrants are typically choosing to reside in a new location. This distinction is, of course, not always black and white. Immigrants may "choose" to leave their homes to escape a variety of situations; in these cases, the contrast between the two categories can be blurred. The stories in Migrant Melodramas often contain similar themes to those in Refugee Dramas. Because these two sub-genres are so similar, I will use elements of 
Migrant Melodramas, brought forth by Puga, to further analyze the relationship between the Refugee Dramas being explored in this paper and Melodrama.

Puga builds off her understanding of Brooks and his 'melodramatic imagination'. This melodramatic imagination creates a way for viewers to organize the world and the perceptions of those in that world. For Puga, this organization is possible in part due to the co-mingling of realism and melodrama present in Migrant Melodrama which "promotes moral reform" and a perception of real people ("Migrant Melodrama and Political Economy of Suffering" 74). Puga also builds off Linda Williams' break-down of a definition of melodrama to create her own definition of Migrant Melodrama.

Summarized, Williams includes five points in her definition of melodrama:

1. The protagonist must embody a just cause, which in many cases is a political conflict that becomes a personal experience.

2. There must be confirmation of the virtue of the protagonist and their cause that conflicts with the undeserved violence the protagonist endures.

3. A clear divide between the virtuous and the villains should be present; the virtuous suffer while the villains cause the suffering.

4. Dramaturgical elements of suspense and complications must appear.

5. Villainy and virtue must be recognized and "accompanied by respective reward or punishment". Though, as Williams points out, this respective reward and punishment is not always brought to fruition in the drama. (“Migrant... Arellano" 359-360).

Puga incorporates these five points into her definition of Migrant Melodrama and adds four more to her definition: 
1. Migrants in Migrant Melodrama suffer as a price for inclusion. When the character is not included, or withheld rights, it is implied that they have not suffered enough to be included.

2. Migrant Melodrama is used as a tool to promote inclusion and basic rights for real-life migrants (specifically in Puga's analysis, mothers and children).

3. There is a power imbalance between performers and the audience. Depending on whom the performance is created by, the power imbalance can satisfy those who hold the power to grant the rights and inclusion mentioned above, or the performance can create a fictional, villainous migrant.

4. Building off the previous point, Migrant Melodrama involves shifting roles that can, depending on the creator of performance and intent, cast characters as specific types of stereotypes.

(“Migrant... Arellano" 361).

These nine points of Migrant Melodrama to some extent are present in plays under the Refugee Drama genre. In the two plays analyzed in this thesis, McLaughlin's The Trojan Women and Ensler's Necessary Targets, the political conflict of the Bosnian genocide quickly becomes a personal experience for each of the characters. The Bosnian and Trojan characters in each play are virtuous characters attempting to survive for a just ending to their story. The violence that the Bosnian/Trojan women face, or faced prior to the action of the play, is undeserved and promotes their virtue. For the most part, the viewer recognized the stark difference between the virtuous victim and villain in each play as well. For Necessary Targets, the villain is never seen, but mentioned. Regarding the clear points of complication and suspense, the death of Astyanax in The Trojan Women is a distinct example. Necessary Targets does not have as explicit points of 
complication, but there are subtle plot complications and suspenseful moments present. Most of these moments develop from moments where psychological trauma is explored in the characters. Finally, the one point where the two plays analyzed in this paper differ from Williams' points is the culmination of reward for the victim. Both playwrights set up an expectation that, to some extent, the women will be rewarded for their suffering. McLaughlin (and by default, Euripides) sets up this expectation that Astyanax will return to Troy, vindicating the fall of the city. Ensler's American characters bring hope of a bright future for the Bosnian women and, perhaps, a resolution to their trauma. But, the audience is denied this satisfactory resolution in both plays. However, as expressed earlier, this is more a trend in melodramas rather than a clear rule that must be followed. Puga's additions will be explored in the following pages of this chapter.

\section{Suffering and Stereotypes in Migrant Melodramas}

Puga's first two additions to her definition of Migrant Melodrama deal with the suffering of migrants as a step to inclusion. This suffering, though often undeserved, is a step that characters in Migrant Melodramas — and arguably in real life — must go through to reach favor in the eyes of those in power. In the case of many Migrant Melodramas, the audience holds the power; the spectator ultimately decides who is worthy of being saved, having rights, and receiving fair treatment in many of these plays even though those creating the performances and the characters appear to have some control over the inclusion of undocumented migrants. Because suffering, especially undeserved suffering, often appears sympathetic, this use of suffering for the sake of inclusion is most often used by advocates for migrant rights "in an attempt to humanize migrants and create a sense that they have suffered enough to "earn" inclusion in a community or a nation-state." ("Migrant... Suffering" 75). To Puga, the sympathetic suffering is "a redemptive sign of moral virtue.". This sign of moral virtue speaks to 
Brooks" "melodramatic imagination" ("Migrant... Suffering 73). Positioning the suffering of undocumented migrants as a moral virtue allows the audience to justify including the migrants into their community or nation-state. When it appears that undocumented migrants have suffered for their inclusion, rights, and fair treatment, their undeserved suffering becomes redemptive in that their transgressions for migrating illegally can be forgiven or looked past.

In Refugee Drama, the refugee characters do not necessarily suffer for the same reasons that characters in Migrant Melodramas do. However, Puga's assertion can help us understand the ways in which suffering in Refugee Drama can be redemptive. In the two plays analyzed in this study, the refugee women suffer or have suffered in the hopes of someday having a peace of mind and their safety restored. This may mean that the characters need the assistance of others. In the case of The Trojan Women, Poseidon could be the help the women need, though this help never comes for them. Suffering needlessly, for the refugee, is redemptive in that the suffering is a way to "earn" the assistance from others and a restoration of safety.

However, this can be problematic. As Puga suggests, the suffering of undocumented migrants can become a commodity for the consumption of the spectator ("Migrant... Suffering" 75). This is quite like the emotional catharsis audiences can feel while watching politically or socially-driven melodramas, such as those found in Refugee Dramas. Puga claims that depiction "of suffering is a web of transactions in which performances of undocumented migrant suffering [is] exchanged in attempts to promote empathy, tolerance of mobility, and respect for migrant human rights." ("Migrant... Suffering" 72). To "earn" inclusion (the commodity), the undocumented migrant character (the buyer) must suffer (the cost). Similarly, the promotion of empathy, tolerance, and respect (the commodity) is bought by the migrant character with their suffering. The obvious problem here is that the character pays with their own suffering in either 
case. In Refugee Drama, the refugee pays with their suffering as well. Performing plays in the hopes of gaining compassion, empathy, and safety from Western audiences becomes a part of the process of commodification of the refugee suffering.

In Migrant Melodramas, two migrant characters appear to suffer most: the vulnerable child and the mother. Though the suffering of these characters is often read as virtuous, this is not always the case. Again, partially depending on the intentions of those creating the Migrant Melodrama, the suffering mother can be imagined as a "good" mother and a "bad" mother. The difference here is that the "good" mother is often depicted as a "worthy victim" whereas the "bad" mother is deemed as unworthy. The "bad" mother, the mother who is depicted as overly sexual, immoral, deceitful in her reasoning for staying in the community she migrated to, and whose children are allowed to migrate alone, can be pitted against the good/worthy mothervictim (“Migrant... Arellano” 356).

The images of the vulnerable child and the suffering mother are recycled from one Migrant Melodrama to another ("Migrant... Suffering” 73). These stereotypes create clichéd characters who are easily identified by the spectator. The often-one-dimensional representation of undocumented migrant mothers, or mothers whose children have migrated alone, can reinscribe "gendered ideologies of the self-effacing and martyred mother." (Hewitt 128). These depictions, exaggerations, and stereotypes are clear characteristics of melodrama and, like melodrama, these images help audiences understand the world around them. Unfortunately, as Puga's interpretation of the "melodramatic imagination" suggests, this organizational way of understanding the world informs perceptions of real people and circumstances ("Migrant... Arellano" 359). These perceptions draw comparison between undocumented migrants and others. 
Like the mothers depicted in the Refugee Dramas discussed in the following chapters, the mothers in Migrant Melodramas, particularly the unworthy mothers, are compared to the ideal mother in the United States/West. Puga claims that, "no matter how much they suffer, they often fall short of an ideal constructed in the nineteenth century for U.S. white mothers, an ideal that relegates the foreigner to the role of someone in need of instruction." ("Migrant... Suffering" 76). The idea that the migrant mothers who fall short of this ideal should be instructed by those who do meet the ideal creates a worldview in which the United States/Western countries are destined to be civilizers of those who need instruction (Kaplan, as cited in "Migrant... Suffering" 76).

This aspect of Puga's argument has greatly influenced my own interpretation of the relationship between the American and Bosnian characters in Necessary Targets. Without detracting from my chapter on Ensler's play, I see two ways in which the role of the Mother is represented through the American characters. Embracing Puga's assertion that Westerners are destined to become civilizers, I argue that there is a direct correlation between the ideal, American woman and the foreign woman/mother in need of aid, and perhaps instruction. The American characters travel to Bosnia to provide assistance for the Bosnian women, yet the Bosnian women never asked for the type of help the Americans were willing to offer. The American characters are representative of second-wave transnational feminism, destined to go unto other nations, specifically those in the Third world, and bring about peace, instruction, and aid.

The similarities between Migrant Melodrama and Refugee Drama do not end there, however. Puga points to Sonia Nazario's journalistic narrative, Enrique's Journey: The Story of a Boy's Dangerous Odyssey to Reunite with His Mother, as an example of how the those in the 
United States/West position themselves as "directors", "narrators", and witnesses to the story of the Other. Nazario, to bring her readers a "true" story of migration, "spent six months in 2000 and 2003 retracing Enrique's steps.”. Nazario, however, was never in the same danger that Enrique experienced or the emotional toll Enrique's mother faced. This "true" experience offered Nazario's readers an alternative person to identify with. Her readers no longer had to identify with Enrique or his mother, but had the option of seeing themselves in "a middle-class professional woman who chooses to suffer in imitation of her protagonist." ("Migrant... Suffering" 78). Nazario, not Enrique or his mother, becomes the suffering, worthy victim. This is like Ensler's journalistic experiences in the Balkans in the 1990s, though Ensler has never claimed to experience the same atrocities as the women she interviewed. This idea of being a secondary witness and the problems of transnational activism will be further explored in the final chapter of this paper.

Melodrama appears to be the foundation to many sub-genres in theatre and film. The use of stereotypes, exaggeration, and plot complications create enticing, yet often challenging productions. These elements of melodrama are clearly seen in the Migrant Melodramas examined by Puga and the Refugee Dramas investigated in the following chapters. The stereotypes of Others, specifically mothers, will be a clear comparison between Refugee Dramas, Migrant Melodramas, and Melodrama. Keeping this in mind, I hope to delineate how stereotypes used in these plays influence the spectator's perception of Others, specifically the perception of refugees. 


\section{CHAPTER III: ENSLER'S NECESSARY TARGET'S}

Eve Ensler wrote her play, Necessary Targets, after visiting the former Yugoslavia in 1994. After seeing a photograph in Newsday of six Bosnian women in 1993, Ensler felt compelled to visit Bosnia and interview women war refugees (Ensler xi-xii). Ensler travelled to Zagreb and interviewed women at the Center for Women War Victims, which was "created to serve Muslim, Croatian, and Serbian women refugees who had been raped and made homeless by war (Ensler, "introduction”, xiii).

Ensler writes in her introduction to Necessary Targets, When we think of war...We think of the moment of violence - the blast, the explosion. But war is also a consequence - the effects of which are not known or felt for months, years, generations. And because consequences are usually not televised, by then the war is no longer sexy - the ratings are gone, consequences remain invisible. (xiii)

The media traditionally covers the moments of violence, but once the violence and excitement ends, the cameras disappear. The struggle to rebuild both structurally and emotionally is rarely covered in the news circuit. These consequences, as well as the depiction of women during and after war, are at the heart of this thesis. Women during times of duress are often shown as helpless victims of their situation and the media uses stereotypes of women to further enforce this image of women. However, once the cameras leave, the stories of the women are abandoned and all that remain in the minds of viewers are the images and stereotypes reinforced by the media.

Ensler felt she needed to tell the women's stories that were abandoned after the news station's cameras left the former Yugoslavia. She believed by interviewing these women, and sharing their experiences with the world, she could not only help the women war victims, but 
also make a deep connection to those who read and saw Necessary Targets performed. This potential connection to others, as well as shedding light on the strength of the women she interviewed, fueled Ensler's desire to write a play in response to the Bosnia-Herzegovina War. She wrote that Necessary Targets was a direct response to the sense of "community, their holding on to love, their insane humanity in the face of catastrophe, their staggering refusal to have or seek revenge" that she witnessed as she lived with and interviewed the women at the Center (Ensler, "introduction", xiv). This observation speaks more to the agency of women Ensler interviewed at the Center, rather than their "victimhood" that was reinforced by the mass media.

Furthermore, Ensler argues that the women she interviewed were indicative of other women war refugees from other nations and, frankly, women and their responsibilities in general:

When we think of war, we do not think of women. Because the work of survival, of restoration, is not glamorous work. Like most women's work, it is undervalued, underpaid, and impossible. After war... Women not only work, but they create peace networks, find ways to bring about healing...They pick up the pieces, although they usually haven't fired a gun. (Ensler, introduction, xiv).

Not only did the women she interviewed have their regular responsibilities to juggle, such as being a caregiver for their families and working a paying job, women war refugees also take on additional tasks. This work towards post-war reconstruction is almost always unnoticed-again, the cameras are not around when this work is being done- and this type of work is nearly impossible to achieve. Yet these women are expected to rebuild their lives, work towards healing themselves and their communities while juggling their everyday responsibilities as well. 
After taking time to reflect on the stories that she heard during her first week interviewing the women at the Center for Women War Victims, Ensler found herself "suspended" in heaviness. She said she "sensed this suspension was a kind of involuntary prayer, a call to make Bosnia matter. To make war matter. But how do you make destruction matter? How do you make people's suffering thousands of miles away matter?”. (Ensler xv).

In this chapter, I will examine three images of women: the mother, the hysterical woman, and the Other, and comment on the way in which Ensler subverts or reinforces these images and the stereotypes surrounding them. Though Ensler's intentions were good when she travelled to Bosnia to interview the female war refugees, it is important to ask whether Necessary Targets inverts the negative image of women successfully. If the subversion fails, the remaining images and stereotypes are reinforced and Ensler could reobjectify the women she writes about. As a middle-class, Western, First-world woman, it would be troublesome for Ensler to reobjectify the women through the retelling of their testimony. There are certainly moments in Necessary Targets where Ensler both reinforces and subverts the traditional stereotypes of women. This chapter will highlight those specific areas.

\section{Production History and Response}

Ensler's first staged reading of Necessary Targets took place in 1996 with well-known actresses, such as Meryl Streep and Anjelica Huston, performing. This reading was staged on Broadway at the Helen Hayes Theatre and raised money for Bosnian refugees ("Necessary Targets"). Other staged readings of the play were performed in London later that year, but perhaps the most interesting reading of Necessary Targets was performed in Sarajevo, Bosnia.

The Sarajevo staged reading was performed at the National Theater with stars like Glenn Close and Marisa Tomei performing the roles of the American women. The Bosnian characters 
were played by Bosnian actors and the reading was performed in front of a crowd of 400

Bosnian refugees (Grossman). This aspect of Ensler's performance is like McLaughlin's The Trojan Women; both plays were, at some point, performed by Bosnians. The implications of performing a play by Bosnian performers, for a mostly Bosnian audience, are similar as well. For Ensler's piece, where the Bosnian women she interviewed had little say on the finished product, one wonders how these Bosnian actors and audience members felt about the way in which their experience was portrayed in Ensler's work. Did they feel their experience was truly represented or that the play simply only touched the surface of their stories?

If the reviews of the realized staging in Hartford, Connecticut, are any indication of the Bosnian's feelings towards this play, it would be useful to question if Necessary Targets is successful at subverting the stereotypes of women used in the play.

Though several critics enjoyed the 2001 production of Necessary Targets at the Hartford Stage, the critics' overall perception was that Ensler still had some work to do. Many felt the brief scenes ended before they really began and the audience never was fully able to grasp the struggles of the women refugees. Charles Isherwood, a critic for Variety magazine and later The New York Times, wrote,

We come away with remarkably few insights into the horrors specific to the Balkan conflict and the scope of the suffering they caused. Ensler gives us a few brief snapshots of pain crammed uncomfortably into a trite dramatic structure. The intensely personal testimony that was such a significant part of the appeal of "Vagina Monologues" has somehow become homogenized into sadly generic drama here. (Isherwood) Isherwood, a tough critic whose reviews held significant power in the theatre world, found the missing link in the performance was the narrative that comes directly from the interviews Ensler 
conducted in Bosnia. The reliance on realism, rather than playing up her prior experience with direct addressing, ensemble playing, and use of interviews in The Vagina Monologues, creates an overused dramaturgy for Isherwood. Whereas The Vagina Monologues used monologues that were directly adapted from the interviews Ensler conducted with other women, the interviews Ensler conducted for Necessary Targets became a form of inspiration rather than a performance of primary testimony. Because of this, the personal narratives that were the source in Necessary Targets are slightly skewed or lost by the time it reaches the audience.

Other critics struggled with the intentional focus Ensler put on the American characters. In an interview, Ensler states that Necessary Targets is about Bosnian refugees, but "it's actually about two Americans who go to Bosnia, as so-called help, and in the process are radically transformed." (Grossman). Though critic Karen Bovard acknowledges that Ensler's piece certainly had its difficulties, she appreciated the focus on the American characters (J.S. and Melissa). Bovard notes, "By centering on the American psychiatrist's story, Ensler avoids the most egregious kind of speaking for 'the other' and thereby committing an arrogant act of imagined empathy, but focuses instead on the changes in consciousness that traumatic events have on Americans from our position of privilege and relative safety." (Bovard). Though this statement is true - the play can create a consciousness of privilege to American audiences - part of Ensler's desire to write this play was to create a sense of connection between her audiences and the Bosnian women. Connection is at the root of the purpose of theater for Ensler. She asserts the purpose of theater is to "experience what we experience [...]. We are there, for these moments together, joined by what we see and hear, made stronger, hopefully by what opens us." (Ensler, "Introduction" xv). Thus, Ensler did intend to create a connection between everyone in 
the theater, and arguably the Bosnian refugees. This could have resulted in an imagined empathy for some.

Markland Taylor, another critic for Variety, disagreed with Bovard. Taylor argued that the "focus on J.S. tends to take audience attention away from the plight of the Bosnian women." (Taylor). It is possible that, especially in the United States, audiences most closely relate to J.S. and Melissa, instead of the Bosnian refugees, focusing their attention on the Americans rather than the true subjects of the play.

\section{Stereotypes in Necessary Targets}

The major problem many critics had with the Hartford Stage production of Necessary Targets is the lack of depth of the characters, specifically the refugee women. Though he recognizes that performing such roles can be challenging, Taylor suggests that all the characters "need more depth and dimension." (Taylor). This problem can be associated with the trouble actors had with truthfully portraying these characters, but inherently stems from Ensler's conception of these women. The flatness of these characters can be attributed to the stereotypes of refugee women that Ensler falls back on. Taylor is not the only critic to notice the stereotypical flatness of the characters. Kerry Reid, a critic for The Chicago Reader, notes that the 2004 production at Apple Tree Theatre had similar problems. Reid describes Necessary Targets as "a disappointing mishmash of docudrama and Lifetime Television clichés.". She also

points to several stereotypes — "the comical peasant woman, the borderline schizophrenic childwoman, and the sex-obsessed middle-aged wife" - claiming that the stereotyping "exoticizes the refugees and trivializes their pain.” (Reid). Relying on these stereotypes to round out flat characters essentially reinforces the images of women that feminists in general have attempted to dispel. 
Part of the problem with putting stereotypes on stage is that the audience has the responsibility and privilege of interpreting them. This can be problematic for the playwright who may attempt to subvert the stereotypes of the characters they put on stage. Ensler was likely driven by good intentions, as she worked with and wrote about women and their stories, but she is one playwright who still falls into the trap of using stereotypes on the stage. One of the ways a playwright can help guide the audience into recognizing the subversion is by creating a clear resolution for the characters in their play. Ensler does not do this. In an interview, Ensler says that she wants "the audience to draw their own conclusions about these characters - and themselves. The ending asks, 'What happens when you're affected by people?' Do you change or do you just hold that inside you? And is holding it inside you a change?”. (Ensler, "Eve Ensler", 171). Without a resolution for the Bosnian women, the audience struggles to see how the women function after their encounter with the American women. Are the refugee women able to create a new life or are they forever traumatized by their experiences? Failing to answer this question creates an opportunity for the refugee women to be interpreted as weak and damaged that can reinforce the stereotypical images in mass media. Ensler's last scene also centers around J.S., an American character. This also implies that J.S. is actually the protagonist of the play, not the Bosnian women. In this last scene, J.S. stands in her apartment talking to Melissa through a tape recorder and describes the ways her life has changed since their visit to Bosnia. The Bosnian women are in the scene; they sit around a kitchen table in Bosnia, making coffee. This indicates that the refugee's life is mundane and does not point to their suffering. Instead, the last scene creates another opportunity for the play to be about the Americans, rather than the Bosnian women. 
Another way Ensler creates opportunities for stereotypes to thrive instead of being subverted is by creating a "stereotypical", feminine environment for the Bosnian women. Isherwood commented on this in his critique in Variety:

Too much time is spent showing the women engaging in generic female bonding: dancing to a Madonna record, slapping on face cream, getting drunk on Bosnian moonshine. Ensler may be attempting to show the slow buildup of trust between the Bosnians, led by the cynical, mannish doctor Zlata (Diane Venora), and the American aid workers, but the result leaves us questioning — yet again — J.S.' professional training, even as the dramatic potential of the play ebbs away. (Isherwood)

By suggesting that the refugee women participate in stereotypical feminine activities, such as dancing to Madonna and putting on face cream, Ensler creates an opportunity for feminine stereotypes to adhere to the identities of the Bosnian women. It is certainly possible that these women used face cream and danced to Madonna before the war, however pointing to these lighthearted activities essentially takes away the seriousness of their situation. These activities are also gendered. The frivolousness of using face cream and drunkenly dancing creates a stereotypical image of the Bosnian women. By using items and music that appear to be feminine, Ensler creates an environment that makes the refugee's situation seem less dire. The refugee women come across as feeling rather comfortable in their situation, which is not what Ensler, any peace activist, or feminist would want.

The stereotype of women as mothers is personified in Ensler's American characters. J.S. and Melissa depict two American women who travel to the "third world" to "help". This transnational feminism was a major form of activism for second-wave feminists, but these American women often created more problems than they solved. Our second stereotype depicts 
women, specifically traumatized women, as hysterical. Though all the Bosnian women are traumatized, according to Melissa, Seada is the one woman who seems to struggle with her postwar life the most. Seada embodies the image of the hysterical woman. Finally, we look at the stereotype of the "sexualized other". The Bosnian characters in Necessary Targets are abstracted versions of the women Ensler interviewed in Zagreb, many of which were sexually assaulted and culturally deemed as “other". There are ways in which victims of sexual assault may be represented without sexualizing and reobjectifying them. Ensler fails to do so. I will examine several pieces of text to further evaluate this point.

\section{Transnational Feminism: An Image of Maternalism}

Ensler would claim she is a feminist and her previously written play, The Vagina Monologues, and interviews surrounding her work are certainly indicative of her feminist intention. However, Ensler is a product of her environment and sometimes her writing seems to fall more into the white, traditionalist second-wave feminist mindset. However, both The Vagina Monologues and Necessary Targets were written during the beginning of the third-wave of feminism; Ensler's visits to Bosnia and other countries also occurred in the 1990s, as well. Ensler grew up during the height of second-wave feminism, and that certainly would have impacted her worldview.

Though identity politics began to be a concern for some feminists during the secondwave, some particularly white second-wave feminists felt that there was a "universal womanhood" and the essential part of this group was that one was a woman. Martha Rampton associates second-wave feminists with the notion of sisterhood and solidarity, regardless of race, ethnicity, religion, sexual orientation, and class. Chandra Mohanty expands on this idea. She argues that, "The assumption of women as an already constituted, coherent group with identical 
interests and desires, regardless of class, ethnic or racial location, or contradictions, implies a notion of gender or sexual difference or even patriarchy...". (Mohanty 55). This idea of "universal womanhood" was problematic as white, American woman still held significantly more privilege than women of color, poor women, and the women of developing countries (Rampton). We see this play out when white, American women would attempt to "help" women in need, based on the white, American interpretation of those needs. Mohanty refers to this as the "third world difference". This difference is the oppression women in "third world" (read: nonWestern) countries face. According to Mohanty, the production of this difference that allows "Western feminists [to] appropriate and "colonize" the constitutive complexities which characterize the lives of women... power is exercised... and this power needs to be defined and named." (54). This power struggle, which Western women experience as the patriarchy, takes form in the relationship between Western and non-Western women. This is precisely what happened in Necessary Targets and, arguably, with Ensler's visit to Bosnia.

In an interview discussing her visit to Bosnia and the refugee women's reaction to her visit, Ensler stated:

The same with the Bosnia piece, Necessary Targets. In Bosnia, the women are so happy you're there to begin with - that anyone who has come from America to see them is a miracle...I cry all the time, I grieve, I live around enormous atrocity, and the lesson I've learned is that if you're willing to live with it, go through it, it doesn't own you. It's when you fear and resist and keep reality away that it begins to own you. (Ensler, "Eve Ensler, $161)$.

Though the Bosnian women certainly may have been happy that Ensler chose to visit them, perhaps we should consider that, based on Ensler's writing in Necessary Targets and her 
experience as a middle-class, American, second-wave feminist, there was a lack of trust between the women she interviewed and Ensler. I also see a problem with Ensler speaking about the happiness of the Bosnian women and, in the next breath, claims that she lives "around enormous atrocity". It is troubling to compare the struggles of the middle-class, American woman to that of a Bosnian refugee who likely was raped, watched their homes and cities be destroyed, and witnessed the mass murder of their friends and family. Similarly, by suggesting that the refugees "own" the atrocities they have experienced, Ensler implies that these women have an autonomy like that of Western, middle-class women, which we know is rarely the circumstance of refugee women.

Ensler's Western, middle-class experience colored her own perception of how her trip to Eastern Europe would play out. She says,

When I first went to Bosnia in 1994 during the conflict, I thought I would go as a detached writer, listen to things and have an answer. What happened is that I was destroyed. I sat for hours listening to stories of women who have been raped and abused. There were horrible, horrible stories. And what I did was cry. I sat and I cried, and I cried, and I cried. I realized that if I showed up as I am, as I lived, as I feel in this body, that I don't get numb. And when I try to be somebody I'm not-like this detached journalist or this writer - then I get into trouble. (Kasilag).

This is troubling for several reasons. As Mohanty points out, as a Western woman writing about what Mohanty refers to as "third world women", can result in the objectification of the "third world woman". Mohanty argues that,

By contrasting the representation of women in the third world with what I referred to earlier as Western feminisms self-presentation in the same context, we see how Western 
feminists alone become the true "subjects" of this counterhistory. Third world women, on the other hand, never rise above the debilitating generality of their "object" status. (71). To Mohanty, the Western feminist creates an interpretation of history, a counterhistory, in which she becomes the center of the story. The Third world woman/the object becomes the Other in the new history. To some extent, Ensler could be guilty of writing a counterhistory to her experience in Bosnia. Instead of focusing on the true subjects, the Bosnian refugees, Ensler focuses on how she was impacted by her experience. A similar situation occurs in Necessary Targets; the play becomes about how the American character(s) have changed after their Bosnian visit, not how the visit impacted the Bosnian women or their situation.

Like Ensler, her American characters thought they were going to be able to detach themselves from the stories they heard from the Bosnian women. Ensler places her American characters, J.S., the New York psychiatrist, and Melissa, the trauma therapist, in a position that somewhat represents herself. These American characters are also representative of how witnessing atrocities first hand can have an effect on people who are thousands of miles away. J.S., especially, is relatively naïve to the challenges she embarks on when interviewing the Bosnian women. Though Melissa has been around war-torn countries, and is in the process of writing a book about women survivors of war, she is slow to understand the needs of the women she interviews. Melissa is a "story vulture" and never stays at one location for long as she is focused on getting as many interviews recorded as possible for her book (Bovard). Neither woman is completely qualified to perform the job they set out to do. Isherwood suggests, "Ensler may be aiming to show the harsh contrast between the coddled life of New Yorkers and the brutalities that are just a plane ride away...by overstating [J.S. and Melissa's] obtuseness.” 
(Isherwood). These same women sit at the core of Ensler's story, which as we explored above, is praised by some, but recognized as problematic by others.

When we first meet the American women in scene one, Melissa is very open about her need to interview the women they meet.

\section{MELISSA.}

I am currently writing a book-investigating the effect of war in that creation and development of trauma, focusing primarily on communities of women, on those specific atrocities that traumatize women... I will need to interview these women. (12)

We do not see Melissa express any sort of concern for the needs of the Bosnian women. From the get-go, Melissa is solely concerned about her own interests - getting the final chapter of her book written. Though her topic is certainly admirable, she comes across as primarily focused on her own work, rather than assisting the refugees. Melissa is a contradictory character and at times appears to be focused on her own needs rather than searching for ways in which to help the Bosnian characters and reinforces the stereotypes at play. In this way, Melissa can be read as the antagonist to the protagonist character, J.S. At other moments, Melissa appears to humanize the Bosnian women. This contradictory aspect of Melissa's intentions and personality may be symbolic of the debate between second-wave feminists regarding their stance on transnational feminism.

In scene two, we find J.S. and Melissa in their barracks at the refugee camp. Used to the comforts of the United States, J.S. struggles to adapt to the circumstances surrounding her visit to Bosnia. 


\section{J.S.}

You'll excuse me, but I need the little comforts You're younger than I. I welcome a bath, clean sheets, and a place to sit to...

\section{MELISSA.}

Poop. These women need those same comforts. They had them all before the war. (19) This is the first glimpse we see of J.S.'s unpreparedness for her visit. During this scene, she is prepared to leave the camp and find a hotel that has the amenities she feels she needs. J.S., it seems in this scene, is unprepared and unwilling to sacrifice her comforts for the sake of the Bosnian women she hopes to help. Melissa shows us the empathy and understanding she has gained throughout her research. This is a rare example of Melissa's empathy, but by equating the comforts J.S. desires to the comforts the Bosnian women enjoyed before the war, Melissa humanizes the refugees. A thin and complex line, however, lies between humanizing the Bosnian characters and reaffirming what it means to be feminine. In this particular scene, the Bosnians are humanized, which can counter a stereotype. By humanizing the women, Ensler creates a connection between J.S. and the Bosnian women; this connection should extend to those in the audiences considering spectators would likely identify with the American characters. However, as we will later see, Ensler begins to rely on familiar stereotypes further into the play.

In the next scene, we encounter another example of transnational feminism that may not work out in the American characters' favor. When J.S. and Melissa meet with the Bosnian women for the first time, J.S. attempts to tell them how she would like the interviews to begin. J.S. says, "We thought we'd start off with group sessions in the morning and afternoon. Two hours per session. We'd like to begin and end on time. So we'd appreciate your cooperation" (24). Though this may appear innocent enough, this example is quite telling of many 
transnational feminists' inability to put the needs of others over their own. J.S. has a set schedule that is convenient for her, but what she does not consider is that this schedule may not be best suited for the women. Perhaps two-hour sessions, twice a day is too much for the refugee women to begin with. Instead of suggesting a schedule and asking for feedback from the women, J.S. somewhat demands their cooperation with her needs in mind and assumes that the Bosnian women trust her.

In this same scene, we witness distrust between the Bosnian and American women. J.S. and Melissa tell the women that they have come to Bosnia to help them talk and sort out their feelings about the war. Azra, one of the refugees, points out that talking is not what the women need. Instead they would like their old lives back, their homes, their livestock, and their traditional foods. This is not realistic for J.S. and Melissa to help with. Zlata, another refugee, finds it funny that J.S. and Melissa would travel such a long way to get the women to talk about their experiences. Zlata laughs and says, "You flew all the way here for that? Two American doctors to "help" a group of poor Bosnian refugees talk about the war? What did you think we were talking about before you came?". (30-31).

This scene is interesting for several different reasons. Firstly, this is the first time J.S. and Melissa tell the Bosnian women why they are there. This is the first time that the Bosnian women are told, by J.S. and Melissa at least, that they need help from someone else, in this case two American women. Secondly, when J.S. and Melissa tell the women that they are there to help them, the first response they receive is from Zlata, the suspicious refugee, who questions how they are going to help them. The subtext here is that the Bosnian women have had many journalists and activists "help" them by writing about their stories, taking pictures, and giving them basic necessities (and some luxury items as we see in scene ten when the women put on 
face masks, donated by the French), but they always leave and do not actually provide the help the women need. Along these same lines, the Bosnian women do not want the "help" the American women offer. Instead, as Azra suggests, they want their old lives back, or at least the comforts of their old lives, such as the food they once ate.

J.S. soon realizes that she is not able to provide the help the Bosnian women really need. In the fourth scene, J.S. and Melissa discuss what they each think would most help the refugee women:

J.S.

Listen. I can't help these women. They need homes, a country, and care. MELISSA.

These women need an outlet for their rage and despair. We are necessary targets. (38-39) At this point, J.S. understands that the refugee women want to live their life the way they see fit. They no longer want to be in limbo, waiting to find their families and return to their homes. J.S. knows she cannot provide this for the women, so she feels useless and unable to help. Opposite of her, Melissa believes that they were beginning to see a breakthrough in their sessions and feels that the women need someone they can throw their rage and negative feelings towards. To Melissa, the best way she can help the refugee women is to become a target for their aggression and fear. This is an example in how the American characters take on the maternal stereotype. Melissa feels she must take on the fear and aggression the Bosnian women hold. By doing so, Melissa is embodying the self-sacrificing mother stereotype. Melissa and J.S. each take on the emotional burdens of the Bosnian women at some point in the play, even if only for a moment. Secondly, by naming the play Necessary Targets, Ensler points how women who travel to other countries to "help" others/Others should become targets, or carry the weight of their burdens. 
This is especially true as Ensler has confirmed that Necessary Targets is more about J.S. and Melissa, and their experience, than the Bosnian women (Grossman). This view is likely inspired by a white, traditional second-wave feminist understanding of the American woman's role in the international community; this is essentially pushing the idea that American women are the "ideal" mothers/nurtures.

\section{Hysteria and the Refugee}

Women have historically been identified as overly emotional, irrational, attention-seekers and having the inability to make decisions. These symptoms have often resulted in a diagnosis of hysteria and are mostly associated with women and femininity. Hysterical women have been viewed as being weak and psychological unsound with little regard to the root of the emotional stress. We see this stereotype applied to all the Bosnian women, some more than others. The women are viewed as traumatized individuals who need help to overcome their emotions and psychological struggles.

In scene three, we witness Melissa explaining to the women why she is writing about them:

\section{MELISSA.}

My writing is not to exploit you. Traumatized war victims... NUNA.

Is that what we're called? Traumatized war victims?...

\section{MELISSA.}

It's not a judgment.

JELENA.

No, worse, it's a life sentence. (35) 
Though Melissa claims she is not passing judgment on the refugees, she is. By categorizing the Bosnian women as "traumatized war victims", Melissa is essentially putting them in a box with other war victims, regardless of differences in circumstance. Melissa automatically equates war victims to trauma and traumatized war victims to helpless people. This is precisely how stereotypes work. By oversimplifying the identities of the refugee women, and their situation, Melissa falls into the trap of letting one refugee stand in for all refugees. This is obviously problematic for the women; Jelena understands that once they have been labeled as the "traumatized war victim", they will never escape that label.

Seada, the young mother refugee, is the most emotionally distressed woman in Necessary Targets. Her experience during the war has caused her tremendous pain — a pain she is unable to confront, and so she imagines she is holding her baby, Doona, in her arms when, in all actuality, she holds a bundle of rags. The other Bosnian women understand her pain and, therefore, go along with Seada's reality; but the American women, specifically Melissa, are unable to fully understand Seada's pain and push her to confront her experience in the war head on.

In scene six we find Melissa and J.S. asleep in their barracks. A dark figure, identified as Seada, climbs into bed with J.S. because she believes J.S. is her mother. This is the first glimpse we get of Seada's instability. We do not know, at this time, that the bundle of rags Seada carries is not a baby (though all the other women in the play know this). Though J.S. would like professional boundaries to be in place, Seada is unable to set, and abide by, these limitations. She so desires to be home with her mother that Seada has created an alternate reality where J.S. has embodied her mother. We catch a further glimpse of this in the next scene. Seada touches J.S.'s face and tells her that she feels safe around J.S. Jelena tell J.S. that Seada thinks she remembers J.S. (54-55). 
The perceived safety Seada finds in J.S. creates a place for Seada where she feels she is closer to her pre-war self. From this scene, one could assume that J.S.'s presence is beneficial and, perhaps, therapeutic for Seada; however, we know that this is not actually the case.

In scene eleven and twelve, we find the Bosnian women using alcohol as a coping mechanism. The women, including J.S., are all drunk by the end of the scene twelve. The following day, in scene thirteen, Melissa scolds the women for getting drunk and finally confronts Seada's mental health:

\section{MELISSA.}

Seada is borderline and should not be getting drunk.

ZLATA.

Seada's doing fine.

NUNA.

Zlata, come on. Seada is pretty screwed up.

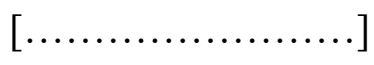

\section{MELISSA.}

Yes, because she has all of us - we support her fantasy world, we agree with her delusions. But she can't rely on us her whole life.

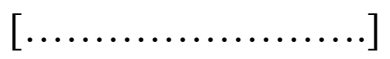

\section{MELISSA.}

Because she's living a lie. She's in complete denial. It's killing her. ZLATA.

No, Melissa. What happened to her during the war is killing her. Her what you call "denial" is keeping her alive. 


\section{MELISSA.}

Barely. She has nightmares almost every night. She's hysterical or wildly depressed most of the time.

\section{AZRA.}

Who isn't? (90-91)

This long, but crucial, scene is important for several different reasons. Firstly, this is the first time that Melissa has outwardly confronted the women for their willingness to disregard Seada's mental health and comply to her alternate reality. Though the Bosnian women recognize that Seada is "pretty screwed up", they also come from a place of understanding. Zlata, the medical doctor, encourages Seada's behavior because she recognizes that Seada is incredibly traumatized by what she experienced during the war. Zlata is afraid that if Seada deals with her emotional baggage, she will harm herself and be unable to function even to the level she does in the current scene. Thirdly, Melissa openly refers to Seada as "hysterical". This, again, puts Seada in another box that could prohibit her from getting the real help she needs. Melissa uses a term which has been associated with a frivolous, female issue when it is obvious that Seada struggles with PTSD. This is an example of how mental illness, particularly "hysteria", has been gendered. Melissa also implies that Seada should be able to dissociate from her PTSD as "hysteria" is often seen as simply being overly emotional, another gendered aspect. Finally, in the dialogue of the other refugee women, we see that they feel similarly to Seada but can function at a higher level. Their ability to function keeps them out of the "hysterical" category when they are placed next to Seada. However, when the Bosnian women are compared to Melissa and J.S., they all become the unstable and hysterical "other" due to their label as "traumatized war victims". 
Later in this same scene, we learn Seada's story from the other refugee women. According to the other refugees, Seada lived with her mother, husband, and new baby. She was the most beautiful woman in her village and her husband hid her when the soldiers came into town to rape the girls. The soldiers eventually found Seada and shot her mother and husband in front of her. Holding her baby, Seada ran as fast and as far away from the soldiers as she could. However, as the other women point out, being chased for hours has its consequences:

\section{JELENA.}

When you are running crazy like that, anything can happen. You can lose your way. AZRA.

You can lose your mind.

NUNA.

Or... your baby. You can lose your baby. You can drop your baby. (94-96)

One can feel the empathy the other refugees feel for Seada. Though they likely did not experience the exact same situation, they can connect to pieces of her story and understand her need to create an alternate reality - for the reality that Seada would otherwise live in is too much for any person to cope with. The other refugees do not place Seada in a category of her own, but the American women do.

\section{Women Refugees as Others}

The women war victims of the Bosnia-Herzegovinian War were targeted because of their religion and ethnicity. These Bosnian Muslim and Croatian women were considered to be the "other" by their Christian Serbian neighbors. Among the weapons used against them was rape and forced impregnation. These women were sexualized others. The exoticism, as well as the ability to potentially deplete the Bosnian Muslim and Croatian blood from Bosnia, sexualized the 
Bosnian Muslim women to Bosnian-Serbs. Similarly, the Bosnian refugee characters in Necessary Targets are also sexualized and considered Others. In this section, we will briefly analyze three characters' experience as the Other and the sexualized Other.

Jelena is a married refugee whose husband suffers from Post-Traumatic Stress Disorder. Her husband was a Bosnian Muslim man who witnessed his brother and father be mutilated and murdered. To cope with his personal trauma, he drinks heavily. Jelena also drinks heavily to prevent her from thinking about her experience during the war. Like many of the other women, Jelena was raped by the opposing military men. This, of course, is difficult for all the women to deal with, but Jelena is only able to escape from her experience when she is drunk.

In scene five, Jelena opens up to Azra about her sexual history with her husband, Dado. She describes an active sex life and brags about how much Dado loves her (41-43). However, later we find out that after the war, Dado will no longer be intimate with Jelena, instead, he physically abuses her. Dado is unable to cope with knowing that his wife has been assaulted and, obviously, somewhat blames her for her assault. Jelena was not only a sexualized other to her attackers, but now she is an "other" to her husband.

Zlata, speaks to how she feels the refugee women are sexualized others to the Western media. In scene eight, Zlata tells J.S. that,

\section{ZLATA.}

...Nothing in our experience prepared us — there were no signs — we weren't fighting for centuries — it didn't come out of our perverted lifestyle — you all want it to be logical— you want us to be different than you are so you can convince yourselves it wouldn't happen there, where you are. That's why you turn us into stories. Then, afterward, we 
become freaks, the stories of freaks - fax, please - get us one raped Bosnian woman, preferably gang-raped, preferably English-speaking. (64)

Zlata recognizes that Western journalists, and in this case, psychiatrists, come to Bosnia to interview them and turn their trauma into stories, instead of focusing on them as people. This is a form of "othering". Zlata also points out that the Western visitors come to hear their stories so they can find comfort in believing that such terrible things would never happen in their home countries - which is exactly what all the Bosnian war victims thought as well. Zlata's final point is that the news stations, journalists, psychiatrists and others only want to interview women who were raped (preferably English-speaking women who were gang-raped, since that makes for a better story). In this sense, the Western media also "others" and sexualizes these women refugees. By solely focusing on rape as the primary atrocity, the Western media could play a part of the romanticism of systematic rape, implying that consequences of rape are less severe.

Another way Bosnian women refugees are sexualized Others is based on their sexual assaults. In scene fourteen, after we bear witness to Seada's story, told by her friends, we see Seada physically trying to harm herself as she describes her experience:

\section{SEADA.}

...those loud deep voices laughing, making fun of me... as they tear off my blouse, these loud, laughing voices wearing black masks, stinking of shit and meat, tear off my milkstained blouse and rip at my aching, full breasts, biting them, sucking, "Okay, Mommy. I'll be your little, dirty baby"- as the other one spreads my legs and the other holds my arms-Doona- "We'll show you how to make real babies, real clean babies. We'll fill you with the right kind of babies." Then he shoves himself into me, and there is a tearing, a ripping, the center of my dress, my underpants, splitting me apart, and as I'm splitting I 
can hear her suddenly, hear her crying out for her mother (wails like her baby), Doona, crying and crying, I cannot stop it, I cannot get it out of my brain. (104).

Seada's story, like so many other war refugees in the Bosnian genocide, describes the sexual assault she faced after witnessing the death of her husband and mother. The line "We'll fill you with the right kind of babies." suggests the "othering" the women of a different religion or ethnicity from their attacker(s) faced. Creating more "right" babies during the Bosnian genocide was a form of "ethnic cleansing" that specifically targeted women and girls. Mohanty expands on this type of othering:

Here, women are defined consistently as the victims of male control— the "sexual oppressed." Although it is true that the potential of male violence against women circumscribes and elucidates their social position to a certain extent, defining women as archetypal victims freezes them into "objects- who- defend- themselves," men into “subjects- who- perpetrate- violence," and (every) society into powerless (read: women) and powerful (read: men) groups of people. (58).

The sexual nature of their attacks dehumanizes the women and further places them in the category of "other". Reading the Bosnian women as victims, unable to recover or help themselves, is part of a larger stereotype of women. In a patriarchal world, often filled with sexual violence, women become an image of powerless and frozen victims. Men are also subject to a stereotype based on the victimization of rape survivors; men, as Mohanty says, are imagined as those who create and act on violence. Though I do not think Ensler intended to create an image of passive victimhood, and may have been recounting a real story of rape, allowing Seada to be a passive victim who was sexualized by men become an Other to women, as well, creates a troubling image of rape survivors. 
Finally, the entire play is based on an "us versus them" attitude between the U.S. and Bosnian characters. To J.S. and Melissa, the Bosnian characters, as a group, are Others. They are different from J.S. and Melissa. This Othering prohibits a true connection to be made between the American and Bosnian characters. Because of this, putting J.S. as the protagonist character, and the likely identification most spectators would have towards J.S. and Melissa, the audiences may be unable to form a true connection to the Bosnian characters as well. Instead, an imaged empathy may take place of a true feeling of empathy.

Though Eve Ensler wrote a play in response to the wars in the former Yugoslavia in the early 1990s, she struggled to create a play that fully dealt with the horrors she witnessed during her multiple visits to the former Yugoslavia. Instead of focusing on the victims of the war, Ensler centers Necessary Targets around two middle-class, American women. Though some critics argue that this is the appropriate format for a middle-class, American woman to create such a response to the war, there are dangers to centering Necessary Targets around J.S. and Melissa. Though there are moments when Ensler is successful in creating an opportunity for viewers to reconsider the use of stereotypes in the play, I believe Ensler misses an opportunity to fully tell the stories of those she interviewed for this project and creates an opportunity for audience members to apply and reinforce harmful stereotypes to the women refugees.

All Ensler's characters are one-dimensional and the spectator is rarely given the opportunity to fully connect with any character, especially the refugees. Ensler falls back on three stereotypes of women and applies them to her characters. The stereotype of the mother/nurturer, the hysteric, and the Other all contribute to the imagining of these characters, and potentially the real Bosnian refugees, as weak and unable to help themselves. Ensler may not have been considering the impact of the stereotypes she may have inadvertently used, but by 
failing to recognize the consequences of using flat characters with clear stereotypical elements, Ensler gives her audiences opportunities to apply these feminized images to actual refugees. 


\section{CHAPTER IV: MCLAUGHLIN'S THE TROJAN WOMEN}

Euripides, an established playwright and Greek veteran in the $5^{\text {th }}$ century BCE, originally wrote The Trojan Women in 415 BCE as a response to the Peloponnesian War (431-404 BCE). The Trojan Women was first performed at the City Dionysia festival, in front of an Athenian audience, and their allies, who were embroiled in a war with Sparta. The playwrights, and subsequently, the message embedded in their plays, were given a political platform as each play was only performed once and many Athenian men would attend each play. Like Euripides, the audience members - who were mostly men - were veterans that could relate to the plot of The Trojan Women after witnessing death and destruction first hand in battle. However, Euripides had an arguably confrontational point of view — he, to some extent, was protesting the Peloponnesian War, the turmoil that Athens was in, and the senseless destruction at the hands of Athenian soldiers.

According to Nicholas Rudall, one of many translators of Euripides' work, The Trojan Women highlights the pain and agony of the civilians in a war-torn nation. Just prior to the 415 BCE festival celebrating Dionysus, Athens had invaded a small island that had chosen to remain neutral during the war, and the Athenian soldiers murdered the men and enslaved the women and children (Rudall 3). In what would generally be considered a militaristic victory, Euripides challenged this perspective to point to the suffering of innocent peoples. To do so, he places the women of the "barbaric" Troy at the forefront of his story. The conquerors "are Greeks: they are the "civilized". In a very real sense, Euripides forces his audience to see its own heroes — the victors of Troy... as cowards who kill and enslave helpless women and children.” (Rudall 3-4). By flipping the legend of the fall of Troy to emphasize the barbarism of Athens' current battle, Euripides added to the debate of Athens' military ethics in the Peloponnesian War. 
Though Euripides takes the side of the victims of war, and points to their suffering, scholars such as Sue-Ellen Case, Jennifer March, Mary-Kay Gamel, and Steve Wilmer, have questioned whether Euripides had a feminist motive. Is it possible that Euripides, a man writing a play about the experience of women during wartime - in which the female characters would all be played by men - for an audience of Athenian, male citizens, could accurately describe the experience of these women? Could he write a feminist play, long before the birth of feminism? Firstly, it is troublesome to apply the term feminist or feminism to someone, such as Euripides, who was alive and working well before feminist thought became mainstream. Applying such a term to Euripides would create friction between the intentions of the playwright and a modern interpretation. However, there are two schools of thought regarding Euripides' take on feminism: those that believe that Euripides is a product of his society, and, therefore cannot be a feminist playwright and those that argue that his strong, female protagonists, the language he chose, and his inversion of legends and myth are indicators of his feminist perspective.

Sue-Ellen Case, a theatre, film and television scholar, is the most prominent scholar rooted in this first train of thought. Case argues that women are imagined in both positive and negative ways in Classical Greek literature. The positive roles of women portray these characters as "independent, intelligent, and even heroic." (Case 317-318). However, there are certainly an abundance of negative images of women in this same period. Characters in these roles were commonly imagined as "the Bitch, the Witch, the Vamp, or the Virgin/Goddess.". Case goes on to say that, "these roles reflect the perspective of the playwright or of the theatrical tradition on women.” (318). These images of women, suggests Case, are a fallacy, which performers and scholars alike should be keenly aware of. The crux of Case's argument in her article, "Classic Drag: The Greek Creation of Female Parts", lies in her assertion that these false images of 
women are a product of the suppression of real women, which then created a falsified image of "woman" within the classical culture (318). Case further states that,

This "Woman" appeared on the stage, in the myths...representing the patriarchal values attached to the gender of "woman" while suppressing the experiences, stories, feelings, and fantasies of actual women. The new feminist approach to these cultural fictions divides this "Woman" as a male-produced fiction from historical women, insisting that there is little connection between the two categories (318).

Case asserts that these male playwrights, in this case, Euripides, created fictional images of women through their female roles, which resulted in further suppression of the actual identities of women in the Classical Greek era. Because he was not a woman and did not allow women to tell their stories in his work, it is nearly impossible for Euripides to write a feminist play. This is especially true when we consider the way in which ancient Athenian women were treated in their misogynist society. ${ }^{3}$ Steve Wilmer tends to agree that Classic texts can be challenging from a feminist perspective. However, Wilmer argues that modern playwrights and directors have found ways to interpret and adapt Classic work to critique both male and female behavior, as well as create empowered female characters (Wilmer 107-108). In these cases, the female roles in adaptations of Classic texts can be feminist.

Jennifer March, a scholar focused on Greek mythology, stands in the second camp. March offers four ways in which we can assert that Euripides, and perhaps other playwrights in Ancient Greece, was not a misogynist: picking portions of text that insinuates his sympathy towards the experience of women; by choosing a whole play, such as The Trojan Women, which puts women and their experience at the forefront; highlighting the positive images of women,

\footnotetext{
${ }^{3}$ For further discussion on Attic women's role in society in the Classical Greek era, see David M. Pritchard's “The Position of Attic Women in Democratic Athens".
} 
which Case mentions, in his plays and contends that such characters could not be written by a man purposefully creating a false representation of women; and, finally, the way in which Euripides manipulates myth to further his message (32-33). March uses this last method to argue that Euripides is not a misogynist by-product of his society.

March analyzes female characters in Greek mythology/plays which are, perhaps, more challenging to sympathize with. March claims that if we can sympathize with these women, we can assume that Euripides was well ahead of his time regarding feminist thought. March argues that by putting women who do wicked deeds on stage (e.g. Medea), Euripides was "teaching compassion and an ultimate forgiveness for these women, and showing an intense pity for the ways in which mankind all too often is brought to grief." (33).

Mary-Kay Gamel, another scholar entering this debate, argues that Case overgeneralizes the plays she analyzes in her article. Gamel also suggests that Case critiques all productions, even modern adaptations, as being troublesome regarding their absorption of the original meaning and purpose (23). By critiquing this aspect of Case's argument, Gamel is also entering a conversation with Wilmer.

March may have a valid argument, in that placing characters in a role that evokes compassion, forgiveness, and pity from the audience may indicate that Euripides had a feminist understanding. However, evoking pity from audiences does not necessarily make someone a feminist. I tend to agree that Euripides' intentions were not feminist in nature. However, I firmly disagree with Case in her interpretation that even contemporary adaptations will take on the subtext of the original text; this does not automatically apply to all adaptations. Firstly, it is challenging to ignore the patriarchal society surrounding Euripides and his work, which would likely have shaped his understanding of the world, and certainly would have influenced the 
reception of his plays. Secondly, the stereotypes of women present in his plays, specifically The Trojan Women, tend to align themselves with the negative images Case outlines in her article. When we examine the images of women present in The Trojan Women, we can identify at least four of the images Case mentions: the Bitch (Hecuba, the Queen of Troy), the Witch (Cassandra, Hecuba's daughter), the Vamp (Helen), and the inverse of the positive image of an independent woman (the chorus of women). These images have been a staple to the imagining of women in literature and are still present in our contemporary plays.

However, not all hope is lost for Classic plays regarding the images of women. When modern playwrights adapt Classic texts, such as The Trojan Women, there is an opportunity for subversion of the stereotypes originally used in these plays. False representations of women created by the patriarchy can be productive in challenging our understanding of contemporary images of women when written with the intent of subversion. However, there is some risk involved in adapting these plays. Not every audience will see the subversive nature of the characters and, sometimes, playwrights may inadvertently enforce the distorted view of women. I hope to demonstrate the ways in which Ellen McLaughlin's adaptation of The Trojan Women succeeds and struggles with subverting traditional stereotypes of women.

McLaughlin's 1995 adaptation of The Trojan Women was, like Euripides, written in response to a war that specifically victimized women. While the Bosnia-Herzegovinian War raged on in the early 1990s, McLaughlin was granted the opportunity to work with a humanitarian organization of her choosing in an effort to use theatre in an unconventional way to reach audiences who may not normally attend a theatrical production (McLaughlin 79). Moved by the Balkan Wars, and the women targeted in these wars, McLaughlin chose to work with recent New York immigrants and refugees from the Balkans. Knowing that she would adapt a 
Greek play, as such is arguably her specialty, McLaughlin says she chose this text and Classic era because,

$\ldots$ they are removed in time and ethnicity from the immediacy of the conflict. I also felt that such texts would connect everyone in the project because we share in them equally as members of Western culture. They belong to no one and everyone. The obvious text in this case seemed to me to be Euripides' Trojan Women. It is perhaps the greatest antiwar play ever written, certainly one of the oldest, and contains some of the most extraordinary roles for women in theatrical literature (81).

McLaughlin's desire to write and direct a play that connected and related to everyone also influenced her casting choices. McLaughlin knew she wanted to work with recent immigrants and refugees from the Balkans, as well as represent and cast people from all sides of the conflict, which created an opportunity to cast non-actors (79). All the performers had experienced much of the trauma that the characters experience in the text, such as the loss of loved ones and the experience of fleeing their home country, and many of the men who performed experienced combat during the war (McLaughlin 80).

To create a play that commented on the Bosnian genocide, and perhaps war in general, yet did not have a clear villain, McLaughlin double and triple-cast each character with someone from each side of the conflict (McLaughlin 82) ${ }^{4}$ This method of casting allowed for each cast member to tell part of their story regardless of race, ethnicity, or gender. In doing so, we can see that no side of any war is fully guiltless of war atrocities and all sides of a military conflict are affected in some manner. This common ground was not only at the core of McLaughlin's vision, but was also true to Euripides' text. By highlighting the barbaric Trojans as victims, and Athens

\footnotetext{
${ }^{4}$ For more information on the Bosnian genocide (and genocide more generally), as well as the United States' response to these genocides, I recommend Samantha Power's book A Problem from Hell: America and the Age of Genocide.
} 
as the perpetrators, Euripides points to how war impacts all sides of the conflict and creates a common thread between Athens and its enemies.

\section{Stereotypes of Women in The Trojan Women}

Though McLaughlin's original script was quite different from Euripides' text ${ }^{5}$, her second version, arranged for educational and regional performances, contains similar language and imagery used by Euripides. Similar stereotypes of women present in Euripides' text are certainly apparent in both versions of her script. In Euripides' The Trojan Women, Hecuba fulfills the image of the mother to both her natural children and the women of Troy. Andromache fulfills the role in McLaughlin's text. This take on Andromache is rather unique to McLaughlin's writing. In the original text (E), Andromache appears to be more concerned with losing her husband and feels sorry for herself. McLaughlin interprets Andromache in a different light. In her text (M), McLaughlin creates a version of Andromache which highlights her love for her son and deep depression after his death. Cassandra, a young prophetess and Hecuba's daughter, is written in such a way as to embody the image of a hysterical and over-emotional woman.

Finally, though all the women in both texts are Othered, Helen's dialogue with Hecuba in the middle of the play perfectly depicts the objectification and Otherness of both the Trojan women and the women performing McLaughlin's original script. ${ }^{6}$

\section{Subversion of Stereotypes}

Feminist film theorist Laura Mulvey suggests that the male spectator often identifies with the male protagonist. This is especially true when the woman/women in the story are objectified

\footnotetext{
${ }^{5}$ In this chapter, I will differentiate between McLaughlin's and Euripides' text by putting an M or E in the citation respectively.

${ }^{6}$ I would like to again point out that in McLaughlin's Balkan Theatre Project (original) script, she chose to cut the role of Helen from the script out of concern that whoever played this role would be the "villain" of the play. After editing the play for universities and regional theatres, McLaughlin added the role back in and wrote several beautiful speeches for Helen that will be further analyzed in a later section of this chapter.
} 
by the male protagonist. Jill Dolan further expands on Mulvey and other feminist film theorists' ideas, that women often struggle to find a non-objectified woman to identify with because the industry has masculinized the spectator (Dolan 48). Women spectators, performers, and characters are essentially "Othered" when the women on screen are objectified. Mulvey asserts that, "the fascination of film is reinforced by preexisting patterns of fascination already at work within the individual subject and the social formations that have molded him" (Dolan 49). These preexisting patterns can be, but are not limited to, replicating power dichotomies and reinforcing gender role - where the male spectator is the subject and women are the passive object/victim. Mulvey believes that to disrupt this model, we must break the expectations and create a new understanding of pleasure (Dolan 49).

This position also applies to theatre as well- however, I argue that the stakes are much higher for the object/woman/spectator because there is no barrier, or screen, between the spectator and the object. When we tell the stories of refugees and other objectified people, we increase the risk of reobjectifying them when we put their bodies on stage, but the opportunity for subversion of the objectification and displayed stereotypes double. This, of course, all relies on the interpretation of the spectator; but, if we can interrupt the expected pattern of pleasure for the spectator, and they are open to this disruption, subversion of these stereotypes has an increased chance of being accepted.

When these characters such as McLaughlin's Andromache, Cassandra, and Helen are performed, the women who play them embody the stereotypes and images of the mother, hysteric, and the (often sexualized) Other. Women, for centuries, have been subjected to these expected roles and images. However, when these same roles are played by refugees and immigrants fleeing war-torn countries, these performers not only provide a body for the 
character, but can also become an object that these stereotypes and images are thrust upon. Though it is nearly impossible to control the way in which an audience will interpret this use of stereotypes, McLaughlin understood that her original audience would likely be non-English speaking refugees, immigrants, and others that came to support their friends and family performing in the staged reading. Because of this understanding of her audience, I suggest that McLaughlin kept such stereotypes in her script (minus the role of Helen which would be added when she was asked to edit the play for other theaters) with little fear that the audience would not see through the stereotypes. Though this may not be her intent, McLaughlin's adaptation seems to subvert these stereotypes by juxtaposing these fabricated images to the independent, intelligent, and heroic women she worked with for her first production of Trojan Women.

\section{The Mother/Nurturer Role}

We start with the character list. None of the characters are given much of a description, but some of the descriptions give us an insight into the images the characters will personify. Behind Andromache's name, we are given the short description of "a mother, twenty/thirties" (McLaughlin 90). This is a great insight into the world of stereotypes these characters and the women performing them live in. Firstly, Andromache is reduced to her motherhood— her ability to reproduce. This first glimpse of Andromache tells us that she is a mother, but does not tell us other facets of her identity. Later in the play we learn that she is Hecuba's daughter-in-law, married to Hector - a great warrior-, envied by many Trojan women, and a woman who, even when her husband is murdered and her city destroyed, is grateful for her life. Along these same lines, in Andromache's character description we are told that she is relatively young, in her twenties or thirties. This age range, today, is the time in which many women choose to have children. We are told that Andromache is a mother, but it is unclear at this point how many 
children she has; one could surmise that Andromache either has multiple children or perhaps would be planning on having multiple children relatively soon based on her age. Though many of these descriptors are problematic for feminist scholars, reducing Andromache to her fertility points to the importance of the role of mothers in the play and the expected role of motherhood in contemporary American society.

We meet Andromache towards the end of the play, directly after the exile of Helen. One of her first lines addresses the loss she has experienced during the Greek raid of Troy the night before. When asked where she is going, when she first encounters the other Trojan women, Andromache responds with, "I go to the Greeks. I take all I have. My son." (M 545).

From the legend of the fall of Troy and previously given information in the play, we know that all the Trojan men were murdered the night before - this includes Andromache's husband, Hector. At this point, all the women know that they will be forced to leave their home and become slaves to the Greeks, taking nothing but the clothes on their backs. Andromache, then, claims she is left with nothing but her only child, her son Astyanax. Again, Andromache is reduced to her motherhood. She has her health, her relationship with her husband's mother, her beauty, grace, and positive outlook on life, yet Andromache insists that her child is all she has left.

As stated above, Andromache is a rather positive person. Though she just witnessed her city being destroyed and her husband's death, she is still able to have an outlook on her life, unmatched by the other women. Understanding that though her life will undoubtedly never be the same again, Andromache asserts,

The dead ask too much of us. I cannot do it. I will find a way to love life. Even in slavery. Even in bondage and 
degradation. It is only my body that can be owned. My mind,

my spirit belongs to me. (M 492-95)

Andromache shows a strength that even the women who fully grasp what is about to happen to them, such as Hecuba - a historically strong, wise female character, do not possess. One could argue that, because Andromache still has Astyanax, she can find some comfort in her loss. If her son is alive, Andromache can find a reason to love life, even when she is abused and assaulted. This position hinges Astyanax's existence to the mental well-being of his mother. Should Astyanax no longer be in his mother's arms, Andromache, in her own mind, would have nothing to live for- her motherhood is the center of her identity.

When Andromache is told that Astyanax will be murdered because the Greeks want to end the heritage of Troy, Andromache has a moment with her son where she tells him how essential he is to her happiness:

ANDROMACHE.

... My darling

boy. Your arms, your belly, your feet, your eyes, your lips.

There is all the joy of life in you. All the hope. You are all and only happiness. (M 556-59).

Even while Andromache knows she is about to lose her son, while he is still in her arms, she finds happiness and hope. Andromache even tells Astyanax that he is her "only happiness". Her son's life and potential future have absorbed Andromache's identity and self-worth. Without her son, her worth is diminished.

Others also placed motherhood at the center of Andromache's identity. Hecuba especially places incredibly pressure on Andromache to not only raise Astyanax by herself, but to teach him 
about Troy, his father, and someday, encourage him to come back to Troy and rule the city again as the rightful heir. When the women realize that some hope lies with the infant, Astyanax, Hecuba places the responsibility of raising the city up again on both Astyanax and Andromache:

\section{HECUBA.}

...And you

have given me my only grandchild. Be careful and raise him

well in his new home. Teach him to remember...

...And let him come back to the hollow

shell of this place and raise it again, long after all of us are

dead. Let him raise his father's city from the ashes and

neglect of history...

...Will you do that? For me? For your father?

Then we will live again. (M 503-14).

Andromache's happiness is not a concern for Hecuba. Hecuba is solely concerned with the future of Troy and ensuring that the rightful heir to the throne of Troy will one day rule again. Hecuba also fails to, in this speech, acknowledge the role of wife and faithful Trojan citizen Andromache has been. Once again, Andromache's motherhood takes precedent. In fact, in this speech specifically, Astyanax's existence has completely subsumed his mother's identity. Mothers are often expected to put their children ahead of their own needs and desires, effectively tying their own identity to that of their child, and this is what precisely happens to Andromache.

Finally, when Astyanax is violently taken from her arms, Andromache is reduced to shambles. She has had the center of her identity torn from her. Her last lines of the play are quite telling of her mental state after Astyanax's death: 


\section{ANDROMACHE.}

I have no strength to save my only child.

It has come to this.

My arms are empty.

I can walk now,

I am light now

Nothing to carry

I can walk down to the ships

And find the passage away from this cursed place. (M 563-73).

There are two things about this speech that we must address. First, Andromache is so overcome with depression that she simply does not have the physical or mental strength to fight for her child. Taking her child away from her has essentially taken her spirit, will to fight, and identity away from her. Secondly, Andromache no longer has the burden of caring for and raising the prince of Troy. She is "light" and she no longer has the burden to carry. Of course, Andromache aches for her child, but there is also a sense of relief in this statement. She no longer must put on a brave face for the other women or find something positive in their given situation because she has had her only joy and happiness taken from here. She can mourn like the other Trojan women.

Like Andromache, we see the refugees in our Western media encounter very similar situations and feelings. When they are forced to flee from their homes, many of the women cannot simply run away and start a new life because they are also mothers. Similarly, the future of their children is often more important than that of their own. We see this when parents encourage their children to flee on their own or when parents leave with their children, even 
when their destroyed cities are the only homes they have known. Images of children sailing without their parents, across the sea to safety in Turkey, have been highlights for the media covering the Syrian refugee crisis. The media uses these images to indicate either the terrible situations parents must be in if floating across the sea in a life raft is safer for their children than staying in their home country or the poor choices of parents in the East.

In her introduction to The Trojan Women, McLaughlin speaks to the challenges the Balkan Theatre Project refugees faced. McLaughlin describes the recent immigrants as those who were "struggling to find places to live, learn English, get jobs, and take care of their children... In addition, many of these people were severely traumatized by what they'd just been through.” (80). Though both the men and women McLaughlin worked with had been traumatized by their experiences during the war, they still managed to care for their children. Like Andromache, refugee parents often suppress their trauma to create a stable life for their children. Though this may come naturally for many parents, it is expected that parents put their emotional instability aside to protect their children.

\section{Cassandra: Hysterical Prophetess}

Dating back to the Victorian era, women have long been considered to be overly emotional. In a contemporary society, we often find that women who are passionate, angry, or express any emotion too strongly are labeled as being melodramatic, crazy, and even hysterical. When women are vocal about their experiences, their stories are often disbelieved. This is especially true when these women's experiences go against the grain of what others' experiences may have been.

Miranda Fricker identifies this denial of one's experience as testimonial injustice. Fricker expands on this idea by noting that the denial of testimony stems from some form of prejudice 
the hearer holds. To some extent, Cassandra, the princess of Troy, experiences testimonial injustice. Though the hearers in Trojan Women are her mother, Hecuba, and the chorus of Trojan women, she is disbelieved when she warns of her death and the death of King Agamemnon. The chorus of women, and especially Hecuba, should be aware of the possibility of Cassandra's fate after they had just witnessed the death of so many of their fellow Trojans and knew of their own fates as slaves.

Cassandra, according to Greek myth, was given the gift of foretelling the future by the god Apollo. In exchange for this gift, Apollo demanded that Cassandra have sex with him (which itself is problematic). When Cassandra refused, Apollo cursed her so no one would believe her foresight. Cassandra warned of the problems that Troy would experience, yet everyone believed she had gone mad and did not know what she was saying.

Though McLaughlin does not specifically address this portion of the myth, we do see Cassandra's inability to convince her mother of the fate she is about to endure. When Cassandra first appears, Hecuba cries out, "It is my mad daughter. My beautiful Cassandra." (M 170-171). These lines are very similar to Euripides' original text; McLaughlin did not take much liberty in her interpretation of Cassandra. This is a case in which the imagery and stereotype of madness being feminine is carried through to a modern adaptation. In this first example, Cassandra's own mother refers to her as being "mad". Cassandra is deemed as being crazy because no one believes any of the warnings she has given in the past. Though her mother does not have a strong prejudice against Cassandra as a person, she does have the preconception that Cassandra is not telling the truth or does not understand what she is saying; this preconception is invalid as Cassandra, as the myth tells, foretold of all the terrible things that would happen to Troy before and during the war. 
Later we catch a short glimpse of Hecuba's denial of Cassandra's foresight: "Oh, my poor child. You don't know what you're saying. You are still in the power of Apollo who loved you and cursed you at once.” (M 200-201). This is different from Euripides' text. In the original text, Hecuba never explicitly says that Cassandra is not telling the truth. Instead Hecuba tells Cassandra that she "thought perhaps the agony of our plight would bring you to your senses. But no, you are still the same." (E 346-347). This is an interesting change for McLaughlin to make; reworking Hecuba, Cassandra's mother, to disbelieve Cassandra's warning creates a striking example of testimonial injustice that the spectator may not have expected. Examples, some of which were discussed in the introduction, of women who have been labeled as hysterical experiencing testimonial injustice are abundantly present; McLaughlin's adaptation is certainly a newer example of that injustice. This is, perhaps, one way in which McLaughlin does not succeed in completely subverting the stereotype of the hysterical woman.

Another difference in McLaughlin's and Euripides' text is the exchange between Cassandra and Talthybius. In McLaughlin's script, there is no exchange or interaction between the two. However, in Euripides' text, Talthybius comments on Cassandra's madness twice: 'It's good that it was Apollo made you mad. Otherwise you'd pay for this [...]" and "All right, you. You slandered the Greeks, you praised the Trojans. But I know you're mad, so I'll let your words fly in the wind." (E 401-415). Talthybius is excusing Cassandra's behavior and implies that she is unable to control herself. This is troublesome as Talthybius' attitude towards Cassandra suggests that she is helpless regarding her behavior and should not be taken seriously which are classic responses to hysteria. McLaughlin excludes this exchange from her writing. This may humanize and paint Talthybius as a more caring and regretful person, rather than a villain like in Euripides' text. This is a good choice for McLaughlin as she wanted to humanize and show the 
suffering of all sides of the Bosnian conflict; if McLaughlin had not removed this interaction, it is likely that Talthybius would be seen as a villain and the person who performed this role would also take on this role of villainy. This lack of exchange between Cassandra and Talthybius may also begin to shift the stereotype of madness. Without this exchange, there is no male perspective in McLaughlin's text regarding Cassandra's hysteria. There is no denial of Cassandra's madness, aside from Hecuba's comments.

McLaughlin created an outlet for the refugees and immigrants she worked with on the Balkan Theatre Project. Without McLaughlin's piece, many of these people may not have had the opportunity to share their stories with others. Many refugees may feel like their stories are not important, or no one wants to hear them or will believe what they have to say, but McLaughlin created a way for their stories to be told. Furthermore, by subtly holding a mirror up to Euripides' work and her own, McLaughlin highlights the similarities between the refugee experience centuries ago and today.

\section{Greece's Object of Desire: Helen and the Trojan Women}

Like the role of Andromache, we begin our analysis of Helen at the character list. Helen is listed as "a beauty, ageless" (McLaughlin, 90). Whereas Andromache is reduced to her reproductive ability, Helen is immediately characterized by her attractiveness. Helen's appearance is important for several reasons, including that a war had just been fought over her. This may seem romantic to some, but as we learn shortly after the beginning of Helen's interaction with Hecuba, she has always been viewed as property — and the Trojan War is certainly indicative of that.

When we first meet Helen, she walks on stage at the beginning of the performance, after Poseidon's opening speech and before Hecuba awakes. In the stage directions, her physical 
appearance and dress are specifically noted: "She is exquisitely dressed, in vivid contrast to the Women she steps around. Her long hair is beautifully coiffed." (M 94). Comparing Helen to the other women is an interesting choice. In doing so, Helen is set apart from the group of women. At the very beginning of this play, Helen is Othered for her beauty. In this Othering, Helen is perhaps viewed as the villain — which is something McLaughlin strongly opposed in the first version of her script - but when we witness Helen's interaction with Hecuba and the chorus of women, she is not depicted in this way. It should be noted that Helen does not appear at the beginning of the play in Euripides' text. This is original to McLaughlin's adaptation and perhaps an example of the Othering present in McLaughlin's version.

In her interaction with Hecuba, we learn that Helen has been raped, enslaved, and viewed as a piece of property for many years. Below are a few selections of the text in which Helen describes her treatment:

Slavery is new to you. No wonder you chafe at it. When you've endured it as long as I have, years and years, you'll learn to stand up to it without so much self-pity.

And then you'll know what I have had to bear. (M, 308-311)

The contempt of the world.

You'll know soon enough. When you rise from your raping beds, wiping your eyes and smoothing your skirts down over your thighs, now purple with your new masters' handprints, perhaps you'll think of me... (ㅆ 313-317) 
This is so familiar.

Bought and bundled one bedroom to the next.

To writhe beneath my many conquerors. (M, 337-341).

In these selections of text, we learn that Helen has been a slave to the men in her life long before her arrival to Troy. We also learn that she has been continuously raped by these same men.

During this interaction, Helen attempts to connect to Hecuba and the chorus of women by explaining that she has been subjected to the same type of treatment they are about to endure when they arrive to Greece. But, because Helen is a villain, and the root of the war, her attempt to connect is rejected. Instead, Helen's story is viewed as being a failed attempt at seeking pity from the women.

In this same interaction, we discover the role Helen believes legend and the gods played in her slavery and the destruction of Troy. Helen claims, "I never had a choice. I was the bride of force. Behind every man who took me stood a goddess [...]." (M 345-346). In this section of text, Helen is possibly referring to Athena, the goddess of war. Athena, in other Greek myths, was known to whisper in the ears of men to persuade them to act in ways in which she wanted them to- often to wage or win a war.

Helen is also angry with the gods because she claims they gave her the gift of beauty, which has been the source of her objectification.

\section{HELEN.}

(As she is taken out.) What I have was given to me by the gods.

It isn't yours to take from me. It belongs to no one, least of

all to me. (M 397-399) 
This selection holds a lot of information about Helen's objectification. Firstly, she blames the gods for her beauty, and therefore, the way in which men have viewed her as property. This selection of text also takes place right before the chorus of women physically abuse Helen in an attempt to destroy her beauty. She asserts that her appearance is not theirs, that they do not have the right to destroy her appearance. This is also an example of McLaughlin critiquing Helen's objectification; by giving Helen a voice, Helen is able to better control her own representation. However, in the next breath, Helen notes that her beauty and appearance has never belonged to her either. This speaks to Helen's objectification and lack of agency.

Finally, Helen speaks to the idea that legend and fate will determine her fate:

You think he'll kill me? After ten years of fighting for me?

For all your wisdom, you know nothing of the truth of men.

He will take me back. It is what legend demands. What it has always demanded... (M 389-392).

This interesting piece of texts deserves analysis because it not only describes the way Hecuba believes a husband will treat their wife after the discovery that she has been unfaithful to him, but we see Helen's belief that legend, the way the story has always been told, will determine her fate. Helen's understanding of how her husband will respond to her return to Greece, simply because other stories have ended that way, is incredibly indicative of how people often respond to power. If we were to translate this to a modern context, this would mean that the men, the wealthy, the privileged will continue to have power and control the way the story is told. McLaughlin flips this on its head, though. By giving active voice to those who do not have power (in this case, the refugee) McLaughlin destabilizes the power relationship. By sharing their stories via McLaughlin's text, the refugees who participated in the Balkan Theatre Project 
hold more power than previously imagined. Euripides does the opposite of this. In a time in which men performed both male and female roles, Euripides gives voice to the men/male actors performing for men. Men held all the power in Greece, which created an environment where Euripides' text was performed for the patriarchy, by the patriarchy.

Finally, Helen speaks so poignantly to the objectification of herself, and other women: “...I am a piece of property. Something to be stolen, hidden, rescued or restored. A statue. A symbol. Nothing more." (M 385-386). At the end of this selection, Helen states that she has been reduced to a "statue" and a "symbol". Statues hold relatively little significance; their main purposes of statures are to be seen, too be aesthetically pleasing, and often mark a historical figure or event. It is interesting that Helen would refer to herself as a "statue"; her purpose, particularly to the men in her life, is like that of a statue. Helen is meant to be seen, not heard. Like many women, her opinion is rarely, if ever, asked for and she is not taken seriously. As stated earlier, Helen's beauty is what sets her apart from other women; her aesthetic purpose, like a work of art, is what is important. Finally, as we learned in a previous selection of text, Helen was "won" back after the destruction of Troy. She is a prize, and has been for many years. She marks the end of a great battle and the victor gets to do with her as he will.

In Euripides' script, this interaction between Helen and the other women is slightly different; Menelaus is present for Helen's speech about why she should not be killed and Helen never speaks to her history of abuse and sexual assault. Instead, Helen defends her actions for running away with Paris by blaming others. McLaughlin's adaptation subverts this image of Helen by telling more of her story of physical and sexual violence. Helen appears as an empathetic victim in McLaughlin's text. However, Helen does not necessarily wear her 
victimhood like a badge, instead she appears strong and composed when the other women attack her.

Helen is not the only "prize" for the Greek soldiers and leaders. The Trojan women are also objectified by the Greek. In his opening speech, Poseidon speaks to the "trophies" the women will become: "And all these women, these sleeping mothers, wives and daughters, Become trophies..." (M 23-24). Hecuba also points to their captivity later at the beginning of her first interaction with Helen: "And how like you, coward that you are, to wait until we are reduced to chattel, slaves at auction, before you dare to walk among us." (M 305-307). In both these selections, we can see the ways in which the Trojan women will be treated. Poseidon understands that the women are viewed as spoils of war. They will become rewards for the Greeks winning the Trojan War. The women are no longer viewed as people, but instead their values are now tied to their purpose as objects. Neither of these passages is present in Euripides' text. Poseidon seems to be solely troubled with the fall of Troy, not the enslavement of the women. Poseidon and Athena conspire to punish the Greeks as they travel home, however there seems to be little remorse or sadness regarding the women and their position. This is another way in which McLaughlin adapts the play and successfully makes the Trojan women empathetic.

In Ellen McLaughlin's adaptation of The Trojan Women, there are three stereotypes of women displayed: the mother, the hysteric, and the sexualized other. By writing the script with refugees from the Balkan wars in mind, and placing refugee bodies on stage as performers, McLaughlin subverts these stereotypes. These three stereotypes are productively used by comparing the body on stage, the stories of the refugees, to the stereotypes portrayed on stage. 


\section{CHAPTER V: CONCLUSION}

Theatre, like other forms of entertainment, holds a significant amount of power in shaping the way audiences think about and react to the work produced. Theatre pieces can reflect the way in which society operates, warning us of what may happen should society continue down its current path, or strive to create a new, perhaps better way of looking at issues. Many modern interpretations of classic plays aim at achieving at least one of these goals. The most recent example is the Public Theater's interpretation of Julius Caesar in their 2017 season of Shakespeare in the Park (New York City). The production, though first performed in the late 1500s, is set in the modern era. Julius Caesar, depicted as a blonde, suit and tie wearing, President Trump, is violently assassinated by Roman senators halfway through the production. Caesar's wife has a Slavic accent, representing the current First Lady, Melania Trump. Though two acts remain after the assassination scene, highlighting the misfortunes of those who attempt to "preserve democracy by non-democratic means", some audiences have argued that the production crosses a line (Oskar Eustis, as quoted in Wahlquist and Beckett). ${ }^{7}$ Protests, on-stage interruptions by audience members, and death threats towards the director, Oskar Eustis, and his family have occurred in the one-month run of the production. Bank of America and Delta Airlines have each pulled financial support from the production, as well (Lunden).

Some of the aims of the production were to look at the potential issues that could arise should President Trump be impeached and explore the futility of violence in the political arena (Wilkinson). Some audiences have certainly reacted to the piece, often citing the Public's perceived condoning of violence towards a sitting president. Though inciting violence was never

\footnotetext{
${ }^{7}$ This is not the first time a sitting president has been portrayed as the titular character of Julius Caesar. In 2012 , both the Guthrie Theatre and the Acting Company depicted then-President Barack Obama as Caesar. Hillary Clinton has also been an inspiration of a Julius Caesar production and performances around the globe put representations of their leaders in the same role.
} 
a goal of the Public's production staff, the production of Julius Caesar has been successful in that the performances have people discussing pressing political issues and questioning the current functioning of democracy, and its consequences, in America.

Modern interpretations like Julius Caesar and The Trojan Women, though different in message, strive to create an environment where audiences can reevaluate their mindsets, opinions, motivations, and political leanings. These political and social works have inspired me to research how the theatre influences the way we look at one another, specifically regarding those we regard as Others. Two of these groups of Others are women and refugees. I chose to combine both groups and examine how traditional stereotypes of women are used in plays, particularly plays about the refugee experience. I have also explored how performance by and about the refugee experience evokes sympathy from audiences in the United States, as well as the potential for subversion or re-inscription of traditionally stereotypical images of women in these plays.

This study finds its foundation in the work others have done on the examination of stereotypes and the role of female characters. I have chosen to situate this exploration in the relatively new genre of refugee drama, with an understanding that plays about the refugee experience have been written and performed for centuries. These elements are not new to theatre scholars, however, combining the use of stereotypes and the refugee drama, as well as exploring how both elements impact each other, is new to the field. This examination of how stereotypes of women, and refugees, are used in plays during a time when women's rights are targeted and a global refugee crisis has emerged, joins the other new works of scholars investigating similar subjects. Also new to the field is further research on McLaughlin's work in general and Ensler's 
lesser known play. McLaughlin's work is under-researched and most scholars have focused on Ensler's The Vagina Monologues.

This paper looks at a small portion of this new exploration of work on refugees in theatrical work. I specifically examined plays written by American female playwrights in response to the Bosnian genocide and refugee crisis. I chose McLaughlin's The Trojan Women and Ensler's Necessary Targets because they were written by women in response to an attack on women. I was also drawn to their work and interviews with Bosnian refugees and immigrants which inspired their respective plays. The primarily female characters and cast influenced my decision to choose both works, as well.

These limitations certainly impacted the research and conclusions I have drawn. Surely looking at refugee dramas written by men, or plays written in response to other genocides/refugee crises, would have influenced this study. Similarly, as the plays in this paper mostly revolve around a female refugee experience, examining a play about the male refugee experience after the Bosnian genocide would have, perhaps, suggested other issues pertaining the male experience.

By exploring the female Bosnian refugee experience and the plays written in response to the refugee crisis in the 1990s, I chose to ground my work in an understanding of Melodrama. Based on my understanding of melodramatic works and that of other scholars who have used melodrama in their research, I find that refugee dramas, The Trojan Women and Necessary Targets in particular, have melodramatic roots. Elements of high emotionalism, a clear division of good and evil, and the use of stereotypes, among other elements are clear similarities to Melodrama. I also tied the refugee dramas I examined to the new, yet established sub-genre of Melodrama, known by film and theatre scholars as Migrant Melodrama. The use of stereotypes 
in each sub-genre of Melodrama evoke emotion in the spectator like the emotions Melodrama thrusts on the spectator. Another tie between Migrant Melodrama and my exploration of women in these plays was the stereotype of the mother. Both sub-genres use the image of the "good" and "bad" mother and works by scholars studying Migrant Melodrama, as well as my own work, highlight the issues that arise when images of a "good" and "bad" mother are created. For me, it was necessary to ground my work in a foundational genre that is known for its use of stereotypes before I explored how stereotypes of women were used in each play in the subsequent chapters.

I then proceeded to examine McLaughlin's The Trojan Women and Ensler's Necessary Targets respectively. In both chapters, I examined three stereotypes that were used in both plays: the mother, the hysterical woman, and the Other. The Other, in this case, often referred to a woman who had been sexualized. These chapters highlighted the ways in which McLaughlin and Ensler were successful in a possible attempt at subversion and ways in which they, perhaps, reinforced traditional stereotypes of women. I also attempted to hint at the consequences of the success of subversion and reinforcement of stereotypes in each chapter.

Through this exploration, pre-existing views of how melodramatic elements are used in modern plays have been challenged. Melodrama is often unfavorably viewed and tends to seem outdated in its use of elements. However, these same elements, particularly the use of stereotypes, high emotionalism, and exploration of good and evil can be useful tools in understanding the impact plays have on audiences. This is especially true when plays are driven by intense political or social matters.

The re-exploration of Melodrama, its usefulness in understanding stereotypes of Others, and the challenges in using stereotypes could potentially benefit the field of theatre studies. This paper also sheds light on a newer genre that may not be as well-known and finds its roots in new 
research geared towards highlighting similar genres with comparable elements. Finally, this paper asks how performances can impact an audience's understanding of others (and Others), as well as the world surrounding the production.

This work opens more doors for further study too. Though I focused primarily on the way in which women and the stereotypes surrounding them are depicted in plays about the refugee experience, there is clear potential for further study on how refugee stereotypes, of all genders, are used in both the two plays examined here and other refugee dramas. Other scholars may wish to further investigate how plays in general, but refugee dramas specifically, impact the audience's understanding of the experience of and views on refugees in a modern setting. Another option would be to explore how newer refugee dramas are being performed and their similarities or differences to The Trojan Women and Necessary Targets, which were written and performed roughly twenty years ago. I would also recommend a comparison between McLaughlin's and other playwrights' adaptations of Classic works.

In a global context, this thesis was greatly influenced by the current refugee crisis and the images surrounding refugees fleeing from Syria to Turkey and other Southern European countries. Many of us still respond viscerally and emotionally to images, circulated through the news and social media, of refugees in a similar manner to those in the 1990s. Headlines such as "These are the Most Powerful Photographs of the Syrian Refugee Crisis..." and "Look At These Photos Before You Say We Can't Take In Syrian Refugees" confirm that the media is capitalizing on the Westerner's interest in victimized Others. These images break our hearts, make us feel as if "that can't happen here", and for a fleeting moment, we feel an emotional response to those images. The question is whether this reaction is empathic in a productive manner or sympathetic, creating a challenging power dichotomy between those in the West 
(particularly in the United States) and Syrian refugees. We consume images of drowned children, crying mothers, dirty families rejoicing their safe arrival to Turkey, militarized refugee camps, and destruction in Syria from the safety of our homes. We embrace the 'us versus them' mentality, if for no other reason than to convince ourselves that we would never be in that situation. Cashing in on the suffering of Syrian families to purchase a feeling that we did a good deed by glancing at the images, is emblematic of the consumption and commodification of suffering.

This study also positions itself in a larger debate in the current political climate in the United States. In a time of contention on the role of refugees and their impact on life in the United States, it is important to explore and find connections between the refugee experience and citizens of the United States. Similarly, when women's rights and their role in the family are questioned and reevaluated, as well an acceptance of sexual violence against women from the current federal administration, it is essential that stereotypes of women and their place in entertainment be examined and evaluated. Perhaps now more than ever, we must explore how theatre impacts an audience's views on "minorities", women, and refugees and develop a better understanding of the power theatre has. 


\section{BIBLIOGRAPHY}

Allport, Gordon. The Nature of Prejudice, Basic Books, 1979.

Aristophanes. Lysistrata, translated by Sarah Ruden, Hackett Publishing, 2003.

"Background Information on Sexual Violence used as a Tool of War." United Nations, www.un.org/en/preventgenocide/rwanda/about/bgsexualviolence.shtml.

Bank, Rosemarie K. "The Second Face of the Idol: Women in Melodrama." Women in American Theatre, edited by Helen Krich Chinoy and Linda Walsh Jenkins, Theatre Communications Group, 1987, pp. 240-245.

Bhabha, Homi K. The Location of Culture, Routledge, 1994.

Billing, Lynzy. "These are the Most Powerful Photographs of the Syrian Refugee Crisis in 2015.” BuzzFeed, 11 Dec. 2015. www.buzzfeed.com/lynzybilling/these-are-the-mostpowerful-photographs-of-the-syrian-refuge?utm_term=.imLDDrROm5\#.wwa88K11eR

"Bosnia-Herzegovina." United States Holocaust Memorial Museum, www.ushmm.org/confrontgenocide/cases/bosnia-herzegovina.

Bovard, Karen. "Necessary Targets (Review).” Review of Necessary Targets, by Eve Ensler. Theatre Journal, vol. 54, no. 4, 2002, 642-643. Accessed 13 December 2016.

Brooks, Peter. The Melodramatic Imagination: Balzac, Henry James, Melodrama, and the Mode of Excess, Yale University Press, 1976.

Case, Sue Ellen. "Classic Drag: The Greek Creation of Female Parts”. Theatre Journal, vol. 37, no. $3,1985,317-327$.

Castellani, Victor. "Everything to do with Dionysus: Urdrama, Euripidean melodrama, and tragedy." Melodrama, edited by James Redmond, Cambridge University Press, 1992, pp. $1-16$. 
Chrystos. “White Girl Don’t.” Not Vanishing, Press Gang Publishers, 1988.

Dolan, Jill. The Feminist Spectator as Critic. UMI Research Press, 1988.

Dorey-Stein, Caroline. “A Brief History: The Three Waves of Feminism.” Progressive Women's Leadership, 22 Sept. 2015, www.progressivewomensleadership.com/a-brief-history-thethree-waves-of-feminism/.

Ensler, Eve. "Eve Ensler". Women Who Write Plays: Interviews with American Dramatists, ed. by Alexis Greene, Smith and Kraus, Inc., 2001, 155-172.

Ensler, Eve. Necessary Targets. Villard Books, 2001.

Ensler, Eve. "Introduction”. Necessary Targets, by Eve Ensler, Villard Books, 2001, xi-x.

Gamel, Mary-Kay. "Staging Ancient Drama: The Difference Women Make.” Syllecta Classica, vol. 10, 1999, pp. 22-42.

Gilman, Charlotte Perkins. The Yellow Wallpaper, edited by Dale M. Bauer, Bedford Books, 1998.

Grossman, Pamela. “"'Down the Vagina Trail”.” Salon, 19 April 2000, http://www.salon.com/2000/04/19/vagina/. Accessed 13 December 2016.

Hall, Stuart. Introduction. Representation: Culture Representations and Signifying Practices, edited by Hall, Sage Publications, 2003, pp. 1-11.

Hewett, Heather. "Mothering Across Borders: Narratives of Immigrant Mothers in the United States.” Women's Studies Quarterly, vol. 37, no. 3, 2009, pp. 121-139.

“Hysteria.” Merriam-Webster, n.d., www.merriam-webster.com/dictionary/hysteria. Isherwood, Charles. “Review: 'Necessary Targets'.” Variety, 28 February 2002, http://variety.com/2002/legit/reviews/necessary-targets-1200551090/. Accessed 13 December 2016. 
Kasilag, Giselle P. “All About Eve.” Business World (Philippines), 26 February 2002.

LaCapra, Dominick. History and Memory after Auschwitz, Cornell University Press, 1998.

—. Writing History, Writing Trauma, The Johns Hopkins University Press, 2001.

Leslie, Victoria. "Fallen Women." History Today, vol. 67, no. 1, 2017.

Lunden, Jeff. “Sponsors Pull Support for 'Julius Caesar' that Seems to Depict Trump, NPR, By Audie Cornish, 12 June 2017. www.npr.org/2017/06/12/532645982/sponsors-pullsupport-for-julius-caesar-that-seems-to-depict-trump.

Maier, Charles S. "A Surfeit of Memory? Reflections on History, Melancholy and Denial." History and Memory, vol. 5, no. 2, 1993, pp. 136-152.

March, Jennifer. “Euripides the Misogynist?". Euripides, Women, and Sexuality, edited by Anton Powell, Routledge, 1990, pp. 32-75.

McConachie, Bruce. Engaging Audiences: Cognitive Approach to Spectating in the Theatre, Palgrave. 2008.

McLaughlin, Ellen. “The Trojan Women”. The Greek Plays, by Ellen McLaughlin, Theatre Communications Group, 2005, pp. 89-118.

McLaughlin, Ellen. Introduction to The Trojan Women. The Greek Plays, by Ellen McLaughlin, Theatre Communications Group, 2005, pp. 79-88.

Mitchinson, Wendy. The Nature of Their Bodies: Women and Their Doctors in Victorian Canada, University of Toronto Press, 1991.

Mohanty, Chandra Talpade, Ann Russo, Lourdes Torres, editors. Third World Women and the Politics of Feminism. Indiana University Press, 1991. 
Mohanty, Chandra Talpade. “Under Western Eyes: Feminist Scholarship and Colonial Discourses." Third World Women and the Politics of Feminism, edited by Chandra Talpade Mohanty, Ann Russo, Lourdes Torres, Indiana University Press, 1991, 51-80.

Monks, Aoife. ““'Genuine Negroes and Real Bloodhounds”: Cross-Dressing, Eugene O’Neill, the Wooster Group, and The Emperor Jones". Modern Drama, vol. 48, no. 3, 2005, pp.540564.

Nahm, Kee-Yoon. “Subvert/Reinscribe: Reading Self-consciously Employed Stereotypes through Performativity." Performance Research, vol. 21, no. 3, 2016, pp. 92-102.

"Necessary Targets.” Simply Streep, http://www.simplystreep.com/content/career/stage/1996necessarytargets.html. Accessed on 13 December 2016.

Parkinson, Justin. “The Significance of Sarah Baartman.” BBC News Magazine, 7 January 2016, www.bbc.com/news/magazine-35240987.

Patmore, Coventry Kersey Dighton. The Angel in the House, Ticknor and Fields, 1856.

Pickering, Michael. Stereotyping: The Politics of Representation, Palgrave, 2001.

Powers, Samantha. "A Problem from Hell”: America and the Age of Genocide, HarperCollins Publishers, 2002.

Pritchard, David M. "The Position of Attic Women in Democratic Athens." Greece \& Rome, vol. 61, no. 2, 2014.

Puga, Ana Elena. "Migrant Melodrama and Elvira Arellano.” Latino Studies, vol. 10, no. 3, 2012, pp. 355-384.

Puga, Ana Elena. "Migrant Melodrama and the Political Economy of Suffering." Women \& Performance, vol. 26, no. 1, 2016, pp. 72-93. 
Rampton, Martha. "Four Waves of Feminism.” Pacific University Oregon, 25 October 2015. https://www.pacificu.edu/about-us/news-events/four-waves-feminism. Accessed 13 December 2016.

Reid, Kerry. "Necessary Targets.” The Chicago Reader, 19 Feb. 2017. www.chicagoreader.com/chicago/necessary-targets/Content?oid=914657. Accessed on 26 June 2017.

"Returns to Bosnia and Herzegovina Reach 1 Million." UNHCR: The UN Refugee Agency, 21 Sept. 2004, www.unhcr.org/en-us/news/briefing/2004/9/414ffeb44/returns-bosniaherzegovina-reach-1-million.html.

Ricchiardi, Sherry. "Confused Images: How the Media Fueled the Balkans War." The Journal of the International Institute, vol. 3, no. 2, 1996, https://quod.lib.umich.edu/j/jii/4750978.0003.215/—confused-images-how-the-mediafueled-the-balkans-war?rgn=main;view=fulltext.

Rudall, Nicholas. Introduction. The Trojan Women, by Euripides, Ivan R. Dee Inc., 1999, pp. 35.

Ruskin, John. Of Queens' Gardens, Ballantyne Press, 1902.

Simons, Marlise. "U.N. Court, for First Time, Defines Rape as War Crime.” The New York Times, 28 June 1996, www.nytimes.com/1996/06/28/world/un-court-for-first-timedefines-rape-as-war-crime.html.

Skloot, Robert. Introduction. The Theatre of Genocide: Four Plays About Mass Murder in Rwanda, Bosnia, Cambodia, and Armenia, edited by Skloot, University of Wisconsin Press, 2008, pp. 3-28.

Smith, James L. Melodrama, Methuen and Company, 1973. 
“Syria’s Civil War Explained from the Beginning." Aljazeera, 16 May 2017, www.aljazeera.com/news/2016/05/syria-civil-war-explained-160505084119966.html. Accessed on 20 June 2017.

Taylor, Markland. "Review: 'Necessary Targets'.” Variety, 6 December 2001, http://variety.com/2001/legit/reviews/necessary-targets-2-1200552369/. Accessed 13 December 2016.

Wahlquist, Calla and Lois Beckett. “This is Violence Against Donald Trump': Rightwingers Interrupt Julius Caesar Play". The Guardian, 17 June 2017. www.theguardian.com/usnews/2017/jun/17/trump-supporter-interrupts-controversial-julius-caesar-play-in-newyork.

Wilkinson, Alissa. "Why Outrage over Shakespeare in the Park's Trump-like Julius Caesar is So Misplaced.” Vox, 19 June 2017, https://www.vox.com/culture/2017/6/12/15780692/julius-caesar-shakespeare-in-parktrump-public-theater-outrage. Accessed 19 June 2017.

Wilmer, Steve. "Women in Greek Tragedy Today: A Reappraisal.” Theatre Research International, vol. 32, no. 2, 2007, pp. 106-118.

Wing, Nick and Chris McGonigal. “Look at These Photos Before You Say We Can’t Take in Syrian Refugees.” The Huffington Post, 16 Nov. 2015. www.huffingtonpost.com/entry/syrian-refugee-photos_us_564a319ee4b045bf3df04d49. 